\title{
AFFECTIVE SENSEGIVING, TRUST-BUILDING AND RESOURCE MOBILIZATION IN START-UP ORGANIZATIONS
}

\author{
Quy Huy
}

Christoph Zott 


\title{
AFFECTIVE SENSEGIVING, TRUST-BUILDING AND RESOURCE MOBILIZATION IN START-UP ORGANIZATIONS
}

\author{
Quy Huy ${ }^{1}$
}

Christoph Zott ${ }^{2}$

\begin{abstract}
Based on a four-year field study of six new ventures, we investigate whether and how founders of new firms engaged in affective sensegiving with diverse stakeholders; namely investors, board members, customers and employees. Affective sensegiving refers to founders' integrating affect in their verbal statements and actions to influence stakeholders' understanding of aspects of their young firms (including themselves). We found a subset of affective sensegiving actionsn- called emotional assuring - that seeks to generate stakeholders' understanding of the young firms or their leaders as displaying (1) socially valued entrepreneurial characteristics, (2) personal caring, and (3) transparent or inclusive organizing. We show how stakeholders interpret these founders' sensegiving actions and that they are likely to mobilize resources when they feel emotionally assured because they perceive trustworthiness. Our study enriches the sensegiving literature - which has mainly focused on cognition - by identifying a range of sensegiving actions that include affect and that build trust. It also extends the trust literature by specifying managerial actions that build, sometimes simultaneously, cognitive as well as affective trust in the challenging context of creating new firms. Lastly, it contributes to the entrepreneurship literature by unpacking the social construction of start-up organizations through founders' use of affective sensegiving actions.
\end{abstract}

Keywords: Affect, emotion, emotional assuring, entrepreneurship, organization creation, resource mobilization, sensegiving, trust.

Both authors contributed equally to this article. We would like to thank Stéphane Côté, Matt Kraatz, Sally Maitlis, Filipe Santos, Nicolaj Siggelkow, Bart Vanneste and Tim Vogus for their feedback on this paper. We gratefully acknowledge financial support from the Kolendorf Fund for Entrepreneurship at INSEAD. We would like to thank Manuela Giangrande, Cesar GuzmanConcha and Wendy Smith for valuable research assistance, and Marie-Françoise Piquerez for excellent administrative support.

\footnotetext{
${ }^{1}$ Professor INSEAD

${ }^{2}$ Professor of Entrepreneurship, IESE
} 


\section{AFFECTIVE SENSEGIVING, TRUST-BUILDING AND RESOURCE MOBILIZATION IN START-UP ORGANIZATIONS}

\section{Introduction}

Founders of new organizations need to overcome formidable challenges. They need to convince various stakeholder groups, including new employees, customers, and investors, that their "new product or service is worth the cost of replacing the old" (Schoonhoven and Romanelli, 2001, p. 389). And they must do so while operating under conditions of uncertainty and being hampered by low legitimacy and lack of a track record. Under these conditions, using affect as part of their social influence actions may help founders foster stakeholders' support for their new ventures, and mobilize their resources (e.g., capital, labor, social networks) to help the young firms (Dorado, 2005; Sirmon, Hitt, and Ireland, 2007). But how exactly do entrepreneurs reassure nervous stakeholders that their ventures are worthy of support? And do they succeed?

Although affect may be implicit in some forms of social influence, extant research has mainly focused on the cognitive dimension of entrepreneurial actions, which include symbolic or impression management behaviors to acquire resources (e.g., Aldrich and Fiol, 1994; Hargadon and Douglas, 2001; Lounsbury and Glynn, 2001; Zimmerman and Zeitz, 2002; Zott and Huy, 2007). This is consistent with the rational, "cool" evaluation criteria (e.g., market size, customer acceptance, key success factors, competitive rivalry, barriers to entry, founders' education, quality of founders' presentations) that resource holders purportedly consider when they evaluate new ventures (Kaplan and Strömberg, 2004; MacMillan, Zemann, and SubbaNarashima, 1987; Shepherd, 1999). Investors and senior executives who are conscious of the business risks of new organizations, in particular, seem unlikely to be swayed by entrepreneurs' affective behaviors or displays (Chen, Yao, and Kotha, 2009).

An emerging stream of largely theoretical work, however, started to question the view of entrepreneurs and resource holders as emotionally neutral, cognition-based decision-makers. Some scholars have posited that, in uncertain or ambiguous environments, affect can have strong effects on entrepreneurs' creativity, persistence, persuasion, employee motivation, and leadership ability (e.g., Baron, 2007, 2008; Cardon, 2008; Cardon et al., 2005, 2009). Affect refers either to a) feelings with no clear cause - "I feel positive" (Seo and Barrett, 2007), or b) emotions as feelings with a cause - "I feel passionate about my venture because it allows me to enact my personal aspirations" (Smith and Ellsworth, 1985).

Unfortunately, very few empirical studies have focused on founders' influencing actions that include affect. Unresolved tensions remain in the entrepreneurship literature as to whether 
cognition-based arguments and actions alone are always sufficient to convince initial stakeholders (including early investors, employees, and customers) to support unproven young firms. We do not know whether stakeholders may be willing to support a new venture based on affect as well as believing cognitively in its promise. High uncertainty and ambiguity that often characterize the process of building new firms could make people more susceptible to the influence of affect (Baron, 2008; Cardon et al., 2009). As a result, influencing actions that include affect (and not solely rely on cognition) could increase stakeholders' willingness to support the young firms. Because stakeholders of new firms have a high need to make sense of ambiguous data, founders' attempts to help these stakeholders understand more clearly aspects of the young firms (including the founders themselves) could be construed as a form of sensegiving. According to Gioia and Chittipeddi (1991, p. 42), sensegiving can be defined as the "process of attempting to influence the sensemaking and meaning construction of others toward a preferred definition of reality".

Mirroring research on entrepreneurs' social influence behaviors, research on sensegiving has focused mainly on cognition, although affect may be implicit in some forms of sensegiving such as communicating a desired future image to foster strategic change (Gioia and Thomas, 1996). Studies on sensegiving, for example, have focused on cognitive content and forms of communication, which could also be useful for founders, such as presenting new labels or underlying meanings (Corley and Gioia, 2004); holding meetings to communicate the leader's vision and disclosing intentions through hypothetical scenario presentations (Gioia and Chittipeddi, 1991); selecting framing language that fits with divergent stakeholder preferences (Fiss and Zajac, 2006); or attracting resource holders' attention to a particular issue (Dutton et al., 2002). Scholars have also explored mostly cognition-related antecedents of sensegiving (e.g., perception of a sensemaking gap) and the conditions that facilitate sensegiving (e.g., issue-related expertise and legitimacy) (Maitlis and Lawrence, 2007). Therefore, we ask the following research questions in this study: Do founders of new firms practice affect-including sensegiving actions to garner support for their ventures and, if so, how do they do this? In what ways and why are such actions consequential for the building of new firms?

As extant theories do not allow us to formulate precise testing-oriented hypotheses to address these questions, we have adopted an inductive qualitative research approach. Relying on the findings of a four-year field study of six nascent firms, we contribute to the sensegiving literature by building a theory of firms' founders' sensegiving actions that include affect. An example of such sensegiving is displaying calm when handling anxious investors. The founders' calm composure makes investors feel assured that the founder is competent in handling stressful situations - a valuable entrepreneurial attribute. Another example of affective sensegiving involves organizing joyful social events for newly recruited employees to celebrate small successes, which produces employees' beliefs that they are valued inside the new company, and that this is an enjoyable and worthwhile place to work.

We call these actions "affective sensegiving," which we define as founders' integrating affect into their actions to influence stakeholders' understanding of aspects of their young firms (including themselves as leaders). This new concept of affective sensegiving can include both affective and cognitive dimensions. In this study, we found a subset of affective sensegiving actions that sought to generate stakeholders' understanding of the young firms or their leaders as displaying 1) socially valued entrepreneurial characteristics; 2) personal caring, and 3) inclusive or transparent organizing. We also found wide differences in founders' propensity to engage in affective sensegiving, and we identified conditions and mechanisms under which this form of sensegiving helped mobilize resources for the firms.

2 - IESE Business School-University of Navarra 
These findings shed new light on the entrepreneurship process. They suggest the social construction of start-up firms through founders' use of affective sensegiving actions. Furthermore, our analysis is consistent with the notion that stakeholders' resources are often not fixed and static, nor deplete with use (Feldman, 2004; Feldman and Quick, 2009). In short, our study reveals the processes by which resources are mobilized - that is, acquired, created, or renewed dynamically through social interaction between founders and stakeholders. The presence of affect in quality relational connections (Dutton and Heaphy, 2003) can foster creation and renewal of resources that stakeholders continuously provide to young firms.

Analyzing stakeholders' interpretation of founders' affective sensegiving actions enabled us to understand and interpret these findings more deeply. After all, stakeholders who made significant resource commitment decisions in novel situations would need to make substantive inferences about the founders and the new firms. However, emotions and their effects can dissipate relatively quickly (Schwarz and Clore, 2006). It was therefore a priori unclear whether affective sensegiving actions could actually "induce" (as in lab experiments) vigilant stakeholders, such as savvy investors and experienced managers who were enticed to join the unproven firms, to provide the kind of substantive support that these firms need. We found that founders' affective sensegiving was more likely to be well received by stakeholders to the extent that it conveyed dimensions of trust, such as ability, competence and integrity (Mayer, Davis, and Schoorman, 1995).

Accordingly, another important theoretical contribution of our study is situated in the literature on trust. With few exceptions (e.g., Child and Möllering, 2003; McAllister, 1995), empirical research has underexplored the agentic and affect-including aspects of trust-building. Scholars have often described trust development as a relatively passive process of gathering information about other people's trustworthiness by observing their behaviors over time (e.g., Lewicki and Bunker, 1996; Ring and Van de Ven, 1994) or by using information from proxy sources (e.g., Burt and Knez, 1996; Zucker, 1986). In particular, trust scholars have paid scant attention to the links between affect-including sensegiving actions and trust formation. Hitherto, we have lacked a textured understanding of what kinds of affective sensegiving actions influence what specific dimension of perceived trustworthiness and why (Mayer, Davis, and Schoorman, 1995). Our study addresses this gap. To highlight the important role of the three types of affective sensegiving actions mentioned above in building stakeholders' trust in the specific context of firm creation, we group them under the umbrella concept of "emotional assuring."

The rest of the paper is organized as follows. We first review the literatures that inform the links between affective sensegiving, resource mobilization and trust development in nascent firms. Then we describe how we collected and analyzed our data. Third, we describe our findings, including the various kinds of founders' affective sensegiving actions, how stakeholders interpret these actions and how these interpretations influence their decisions to provide resources to the young firms denoted as resource mobilization. We conclude by discussing how our study contributes to the literatures on sensegiving, trust and entrepreneurship, and suggest areas for future research.

\section{Affect, Sensegiving, Resource Mobilization and Trust in Young Firms}

In this paper, we build on Gioia and Chittipeddi (1991) to define affective sensegiving as integrating affect into actions aimed at influencing others' understanding of aspects of young 
firms and their founders. Affective sensegiving can be related to other social influencing concepts. It could be considered as subset of impression management (Gardner and Avolio, 1998), but is different from the usual portrayal of impression management in the literature as disguising or covering-up reality (e.g., Westphal and Zajac, 1998; Zbaracki, 1998). Affective sensegiving, as we construe it, does not have this connotation of intentional deception. At the same time, affective sensegiving does not require influencing actions to be always intentional: some can be quasi-unconscious. Another related concept is emotion management, which involves actions that elicit, maintain, or modify other people's affective states (e.g., Barger and Grandey, 2006; Hochschild, 1983; Rafaeli and Sutton, 1991). We construe affective sensegiving as more general than emotion management, in that the former involves actions that include affect in combination with cognition without a strict requirement to actually elicit, maintain, or modify other people's affective states. Affective sensegiving can, but does not have to, alter other people's affect.

Empirical research on entrepreneurship has so far underexplored affect-including sensegiving actions and their effects on resource mobilization. Resource mobilization means the support (e.g., in terms of labor and economic and social capital) that various stakeholder groups (e.g., early investors, newly recruited employees and first customers) provide to the firm. A few studies have considered this form of influence as part of broader research into entrepreneurs' political and social skills. But these studies have not produced consistent results. For example, researchers have examined the affect-related constructs of "expressiveness" - the ability to express one's emotions and feelings (Baron and Markman, 2000, 2003; Baron and Tang, 2009) - and "passion" (e.g., Baum, Locke, and Smith 2001; Baum and Locke, 2004; Chen et al., 2009). Baum and Locke (2004) argued that "passion" influences founders' competence and motivation, positively impacting venture development. In contrast, Chen et al. (2009) found that "passion" does not matter for resource mobilization, echoing prior conjectures about investors' preponderance for cognitive evaluation criteria (Kaplan and Strömberg, 2004; MacMillan, et al. 1987; Shepherd, 1999).

Scholars increasingly argue that emotion and cognition cannot be studied independently of each other, but that only an integrative view will lead to an understanding of their effects on entrepreneurial phenomena (e.g., Baron, 2008; Michl et al., 2009). Cognitive science research has proven a strong link between emotion and cognition (e.g., Damasio, 1994, 2003; Lazarus, 1991). For example, research on affect (e.g., Elfenbein, 2007; Schwarz and Clore, 2006) suggests that, faced with uncertainty and incomplete objective information, potential resource holders might consider their affective states as additional information when making decisions to support or join the young firm. Schwarz and Clore (1988) have argued that, when people make evaluative judgments (e.g., about the potential success of the young firm), they unconsciously ask themselves "How do I feel about this?" Affect has been shown to influence thinking and behavior, especially in the face of uncertainty (e.g., Tiedens and Linton, 2001; Seo and Barret, 2007). As business competence and efficiency cannot be proven in the early days of young organizations, resource holders might rely on affect more than is commonly assumed to decide whether they should support the venture. In uncertain and ambiguous entrepreneurial environments, attempting to influence stakeholders' affective states (Forgas and George, 2001) in conjunction with their cognitive interpretation of the founder or firm could tip the balance, prompting these stakeholders to mobilize their resources for the new firms. An important reason for why this might be the case could be the development of trust between founders and stakeholders. 


\section{Affect and Trust development in Young Firms}

Trust refers to a person's willingness to be vulnerable to the actions of another party, based on the expectation that they will perform a particular action important to that person and irrespective of their ability to monitor or control the other party (Mayer et al., 1995). Emerging conceptual research on interpersonal emotion management and collaboration has hypothesized trust as a means of regulating the threat of opportunism between various parties (Williams, 2007). This threat is likely to exist in the minds of firm founders and their stakeholders, at least initially, and it might be exacerbated by the presence of uncertainty (Williamson, 1975). As a result, in young ventures in particular, stakeholders can feel vulnerable to the threats of opportunism. At the same time these stakeholders are often required to make substantive investment of their resources, such as financial or social capital and/or labor, which exposes themselves to risks of underperformance and failure (Aldrich and Ruef 2006; Thornhill and Amit, 2003). The presence of some level of trust in founders' intent and actions could facilitate stakeholders' willingness to provide their resources to the unproven firms.

Trust has been shown to foster discretionary behaviors and cooperation and to supplement the efficiency of formal contracts (Uzzi, 1997; Puranam and Vanneste, 2009). It provides firms with benefits such as more access to "richer-freer" information or increased risk-sharing (Powell and Smith-Doerr, 1994), and also increases motivation to devote resources to joint goals (Dirks and Ferrin, 2001). Trust can be particularly important in situations of high uncertainty, when stakeholders harbor doubt about the venture (McMullen and Shepherd, 2006).

Prior work has conceptualized trust as a product of two factors: an individual's propensity to trust and an individual's expectations about a trustee's future behaviors (Dunn and Schweitzer, 2005). Scholars have suggested that perception of the trustee's level of trustworthiness is captured by three factors: perceived ability, integrity and benevolence (e.g., Butler, 1991; Gabarro, 1978; Mayer et al., 1995). Each factor contributes cumulatively to trust development. Ability refers to the group of skills and competencies that enable a party to act effectively within some specific domain (e.g., expertise in a specific work area). The relationship between integrity and trust involves the perception that the trustee adheres to a set of acceptable principles: in particular, maintaining consistency between words and actions (Whitener et al. 1998). Benevolence is the extent to which a trustee is perceived to want to do good for others, aside from an egocentric profit motive. In uncertain situations, people such as venture stakeholders can unconsciously use affect as additional information to make evaluative judgments (Schwarz, 1990), especially those that are complex or affective in nature such as trust judgments (McAllister, 1995; Williams, 2001). We explore such influence in the study below.

\section{Methods}

We adopted an inductive theory-building research design (Eisenhardt and Graebner, 2007; Yin, 1994) because there are many possible kinds of affective sensegiving actions that entrepreneurs can use, and it is not clear which of them they actually practice or even whether they use any at all. Prior research has not established the precise implications of affective sensegiving on resource mobilization in the context of new firm building. We therefore conducted a four-year, real-time, longitudinal and concurrent study of six nascent ventures, all of which were based in London, United Kingdom, where founders reported varying levels of affective sensegiving. In addition, we investigated how venture stakeholders responded to such actions. 


\section{Sample Selection and Data Collection}

To identify entrepreneurs who had recently launched new firms or were in the process of creating them, we searched a business school's database of alumni who had indicated in a survey administered during an alumni reunion that they had become involved in entrepreneurial ventures after graduation. The resulting list contained 230 names in the United Kingdom. We contacted all by e-mail and explained the purpose of our research. We asked them to identify themselves if they 1) had launched a company within the past 18 months or were planning to do so in the next six months; 2) had their headquarters in the Greater London area, and 3) were willing to participate in a research project that might involve a substantial time commitment. We guaranteed participants complete confidentiality and anonymity. We aimed to study entrepreneurs in the early stages of creating their companies for two reasons: First, we wanted to avoid sampling based on outcomes and, second, most researchers have ignored these early stages. We focused on a confined geographical area to minimize sample variation due to environmental factors (e.g., sociopolitical context, business climate, available resources).

We received 83 replies. After several interactions with these potential firms, we retained an initial set of 26 ventures that seemed to suit our criteria: They were based in London and had materially started up during the period we specified. Initially, we intended to study entrepreneurial behavior broadly; our focus on affective sensegiving of stakeholders, trust building and its importance for resource mobilization emerged only a few years later during our iterative data analysis. Most of the ventures in our sample started between 1999 and 2001. When we began our research in late 2001, they were at such early stages of development that predictions about their eventual success were premature.

We began by recording entrepreneurial behavior (both in real time and retrospectively) by interviewing the founders. Most had graduated from the same top-tier business school, had very high GMAT test scores, had several years of professional experience before enrolling in the MBA program, and had access to the school's vast and high-powered alumni network. In this way, our selection controlled for key aspects of human capital, such as educational background, analytical skill and managerial experience, as well as aspects of social capital - all of which are usually considered as sources of heterogeneity in entrepreneurial ventures. We thus followed Gartner's (1985) suggestion to increase the homogeneity of entrepreneurial sub-groups and look for variations within them to develop precise mid-range theories.

Beginning in February 2002, we conducted face-to-face interviews, mostly at work sites, with all the entrepreneurs in our sample, establishing personal rapport with each of them individually. Each interview lasted between one and two hours. A second round of interviews took place between October and December 2002, a third in October-November 2003, and a fourth in January-February 2005. For these later rounds, we relied mainly on telephone interviews, each lasting between 30 and 90 minutes. We interviewed stakeholders between November 2005 and July 2006. In all cases, we recorded and transcribed the interviews and made extensive notes. We asked our informants to provide comprehensive accounts of their activities since the earliest days of their ventures. In replying to these questions, our informants often mentioned affective sensegiving actions and emotionally charged situations without any prompting. We also asked open-ended questions that triggered concrete examples of affective sensegiving such as the following: Can you tell us about some emotionally high and low moments in the last period? How did you deal with them? How did you convince potential investors or motivate your employees? 
As our interviews with these 26 founders progressed, we narrowed our focus to six ventures that we believed would allow us to explore in-depth affective sensegiving and its influence on firm-level outcomes. First, based on our interviews with these 26 founders, we noticed the prevalence of emotional experiences in the context of building new firms. Most entrepreneurs who spoke to us reported emotionally intense situations. Many of them referred to the process of creating a new business as an "emotional rollercoaster." We found, however, that there were stark differences in the way entrepreneurs described their affective experiences: some presented very richly textured accounts of emotional situations and how they dealt with them, whereas others presented very terse ones - even when describing situations that could have been intensely emotional, such as the firing of a partner. The frequency of their accounts of emotion-laden events also tended to be low even when we explicitly probed for a description of emotionally high and low moments in their recent past. This first step helped us focus our attention on six cases with noticeably rich or terse accounts of emotions. Second, we quickly noted sharp distinctions among founders' ways of considering affect when addressing other people. Some founders appeared to attend to this aspect more often and in a wider variety of ways than others. From that, we surmised that affective sensegiving of other stakeholders (and not just the regulation of one's own emotions) was potentially important. The founders of three of these six ventures exhibited noticeably high levels of affective sensegiving, and the other three displayed low levels (we will elaborate on this in the findings section).

Focusing on only six cases enabled us to interview a wide range of venture stakeholders in each, something that would have been difficult with a larger number of ventures. Indeed, we expended significant effort on convincing the six founders to give us access to their important stakeholders - co-founders, investors, employees, board members and spouses. We surmised that close spouses likely knew how founders dealt with other people's emotions. These sources, as well as our longitudinal design, enabled us to triangulate our findings to build stronger interpretations (Yin, 1994). Some of the questions that we asked these stakeholders were: Have you (and/or the founder) experienced any emotionally intense moments with the venture? How did you interact with the entrepreneur or with others to deal with these situations? How would you describe the relationships among various people in the venture? How would you describe the founder? Interviews with these third parties lasted between 15 minutes and two hours.

We thus followed Eisenhardt's (1989, p. 537) recommendation for a theoretical sampling approach that involves between four and ten extreme cases in which the phenomenon of interest is "transparently observable." Using a limited number of cases enables researchers to find a balance between generating a reasonably textured theory and having to cope with large amounts of data (Brown and Eisenhardt, 1997). We cannot (nor do we wish to) claim that affective sensegiving is the only means to build support for new ventures. Our primary intention with this paper is to examine the outcomes and boundary conditions of affective sensegiving, and not to prove or disprove the effectiveness of other forms of social influence.

Table 1 presents short descriptions of our six cases (the names of the companies and respondents are disguised to ensure confidentiality). The ventures in our sample are active in different industries: hotel management (BUDGET), beverage production (DRINK), consulting services (CONSULT), online retailing (INCUBATE), financial services (INVEST), and wireless communications (TECH). All entrepreneurial teams were first-time founders, apart from the founder of DRINK who had limited entrepreneurial experience in a different industry. 


\section{Table 1}

Cases and Interviews Per Case

\begin{tabular}{|c|c|c|c|c|}
\hline Case & Business Description & $\begin{array}{l}\text { Founder } \\
\text { Interviews }\end{array}$ & Interviews With Others* & $\begin{array}{l}\text { Interview } \\
\text { Total }\end{array}$ \\
\hline BUDGET & $\begin{array}{l}\text { Formed in September } 2001 \text { to operate high-quality limited service hotels. Develops sites } \\
\text { for new budget motels in partnership with financiers and brand owners. Negotiates } \\
\text { license agreement, interprets brand standards, implements these standards and } \\
\text { optimizes required resources. }\end{array}$ & 4 & $\begin{array}{l}11 \\
\text { (co-founder, } 2 \text { senior executives, } \\
2 \text { middle managers, lawyer, } \\
\text { chairman of the board, investor) }\end{array}$ & 15 \\
\hline CONSULT & $\begin{array}{l}\text { Founded in May } 2000 \text { by former partners of a well-known large global IT consulting firm. } \\
\text { Provides IT-supported consulting services to large and medium-sized companies. }\end{array}$ & 4 & $\begin{array}{l}5 \\
\text { (co-founder, } 2 \text { employees, } \\
2 \text { investors) }\end{array}$ & 9 \\
\hline DRINK & $\begin{array}{l}\text { Founded in September } 2002 \text { to build a whisky distillery with a production capacity of } \\
40,000 \text { cases per year. At the same time, produces and markets a range of innovative } \\
\text { spirits using only natural ingredients for consumers of alcoholic beverages around the } \\
\text { world. }\end{array}$ & 4 & $\begin{array}{l}7 \\
\text { (2 co-founders, } 2 \text { employees, } \\
2 \text { board members) }\end{array}$ & 11 \\
\hline INCUBATE & $\begin{array}{l}\text { Founded in December } 2000 \text {. Originally aimed at helping large companies develop new } \\
\text { ventures. Then changed business model to acquiring ailing on-line retail businesses (e.g., } \\
\text { pet food and gardening products), consolidating these businesses and running them on a } \\
\text { common IT infrastructure. }\end{array}$ & 4 & $\begin{array}{c}2 \\
\text { (co-founder, wife) }\end{array}$ & 6 \\
\hline INVEST & $\begin{array}{l}\text { Provides financial services and specialist financing for European early-stage hi-tech } \\
\text { companies, especially in biotech, computing and communications infrastructure. After } \\
\text { several years of operations, in } 2002 \text { essentially had to wind down first fund and get } \\
\text { restarted as a company by raising a new fund. }\end{array}$ & 4 & $\begin{array}{l}3 \\
\text { (2 senior executives, former } \\
\text { investor and board member) }\end{array}$ & 7 \\
\hline TECH & $\begin{array}{l}\text { Founded in December } 1999 \text { to provide wireless telephony solutions for offices and } \\
\text { factories. Develops technology that turns mobile phones and headsets into extensions of } \\
\text { corporate networks and gives portable data devices and smart phones access to local } \\
\text { area networks. }\end{array}$ & 4 & $\begin{array}{l}8 \\
\text { (co-founder, former chairman of } \\
\text { board, senior executive, middle } \\
\text { manager, wife) }\end{array}$ & 12 \\
\hline TOTAL & & 24 & 36 & 60 \\
\hline
\end{tabular}

* Others include co-founders. Some stakeholders provided more than one interview. Therefore, the interview count in each cell of this column might be greater than the total number of stakeholders.

8 - IESE Business School-University of Navarra 


\section{Data Analysis}

We used the case-replication method, in which cases serve as independent experiments that either confirm or reject emerging insights (Eisenhardt, 1989). We focused on founders' affective sensegiving of other stakeholders. We analyzed statements made during our interviews and assigned them to various categories of affective sensegiving actions that founders might use. To avoid biasing our findings toward "successful" affective sensegiving actions, we coded these statements irrespective of any associated outcome, and it was only later that we looked for the consequence, if any, of each of these actions (at which point we found that, although many affective sensegiving actions can be causally linked to organization-level resource mobilization outcomes, as we will show in the findings section, some cannot).

We considered founders to be engaged in affective sensegiving only when 1) we could identify some aspects of themselves (e.g., who they are or what they think, feel or do with regard to their venture) or their new firms (e.g., what the new firm is or does, or how it is organized and managed) that they highlighted to other people, and 2) when the account of their influencing actions included an affect-laden term. The latter could be explicitly expressed (e.g., fun, pride, hope, fear). Cognition and emotion, moreover, are closely intertwined inasmuch as cognitive appraisals are often necessary to elicit emotion (Lazarus, 1991). For example, when people feel angry, they tend to perceive the situation as unpleasant, that other people intend to cause harm, and that they are certain about what is happening. This appraisal pattern can be contrasted with that of fear, for which people assess the situation as unpleasant, the causal event or outcome is uncertain, and they have little control over the situation. As illustrated, these appraisals tend to focus on a small number of dimensions including appraisals of certainty, goal achievement, personal wellbeing or personal control (Smith and Ellsworth, 1985).

Working independently, we each coded founders' affective sensegiving actions based on the construct definitions above, then compared our results and discussed disagreements. Then we went individually through the codes to identify outcomes associated with these founders' actions. Again, we compared our results and discussed disagreements. If we could not reach consensus on either affective sensegiving action and/or its link to (or lack of) specific outcomes, we dropped the respective quote.

During interviews, the individual founders reflected on their reactions to specific events or important personal goals. The emotions, events or goals they reported were often of an enduring nature and could be reproduced mentally in a relatively reliable manner (e.g., anxiety about the uncertainty of their investments or potential personal failure), as opposed to inconsequential, episodic emotional experiences that could be forgotten quickly (e.g., reporting on being inconvenienced by catching a cold) (see Cardon et al., 2009; Robinson and Clore, 2002). For each of these quotes, we identified first-order concepts (Van Maanen, 1979): situationally specific factors closely connected to founders' affective sensegiving, with regard to aspects of themselves or the firm they highlighted or displayed, such as entrepreneurial background, achievements, commitment or energy, or customized attention to stakeholders' needs (see Table 2's columns "first-order concept definition" and "first-order concept label").

In the second step, we engaged in axial coding (Strauss and Corbin, 1998) to build up more abstract second-order themes that applied over multiple first-order concepts. This step yielded more abstract and robust descriptions involving three main types of affective sensegiving actions that display 1) socially valued entrepreneurial characteristics; 2) personal caring of stakeholders, and 3) inclusive or transparent organizing (see Table 2's column "second-order theme"). We found that a fourth category of affective sensegiving actions evoking threat was used as well, albeit less frequently. We explain it briefly in Appendix A. 


\section{Table 2}

Affective Sensegiving Reported By Founders

\begin{tabular}{|c|c|c|c|c|}
\hline $\begin{array}{c}\text { Representative quotes for affective sensegiving } \\
\text { (Code denoting affect-laden term in bold: explicit affective term or implicit } \\
\text { through cognitive appraisal theory) }\end{array}$ & $\begin{array}{l}\text { First-order concept } \\
\text { definition }\end{array}$ & $\begin{array}{l}\text { First-order } \\
\text { concept label }\end{array}$ & $\begin{array}{l}\text { Second-order } \\
\text { theme }\end{array}$ & $\begin{array}{l}\text { Evidence } \\
\text { strength }^{*}\end{array}$ \\
\hline $\begin{array}{l}\text { "The chairman [of the private equity fund I approached] had a personal } \\
\text { family trust, and everything I was saying hit a lot of bells with him of how } \\
\text { his family had made its money. They were in a remote area. They set up } \\
\text { an insurance firm, they were politically astute, they were quite innovative, } \\
\text { they had fun, there was a lot of drive, there was momentum, and } \\
\text { apparently personally I reminded him of his grandfather...so in the first } \\
\text { week of January, I had a call with an outline term sheet saying, we want to } \\
\text { put a million in. It's like, you're kidding?" (Founder DRINK.) } \\
\text { "[Another potential investor] said well I see your team and I can admire this } \\
\text { and I can see you've got relevant experience... The next morning I met him } \\
\text { at the hotel for breakfast and he said, actually l'd like to talk to you-are } \\
\text { you up for sale? I thought .... It's sincere. It was that bit of myself and } \\
\text { himself which were absolutely in alignment. Very little else would be, } \\
\text { very, very little else. l'd be too academic for him, not enough engineering } \\
\text { rolled up my sleeves. But on that bit [i.e., having built a team for a new } \\
\text { venture] we could connect and that was actually what we required." } \\
\text { (Founder DRINK.) }\end{array}$ & $\begin{array}{l}\text { Affective sensegiving } \\
\text { (AS) in interactions } \\
\text { with venture } \\
\text { stakeholders by } \\
\text { identifying and } \\
\text { emphasizing those } \\
\text { aspects of the } \\
\text { founders themselves } \\
\text { (e.g., personal } \\
\text { background, attitudes } \\
\text { such as commitment, } \\
\text { energy), which are } \\
\text { valued by or are } \\
\text { personally meaningful } \\
\text { to the stakeholder. }\end{array}$ & $\begin{array}{l}\text { AS through } \\
\text { invoking } \\
\text { entrepreneurial } \\
\text { background, } \\
\text { attitudes, or } \\
\text { achievements }\end{array}$ & $\begin{array}{l}\text { AS by displaying } \\
\text { valued } \\
\text { entrepreneurial } \\
\text { characteristics }\end{array}$ & $\begin{array}{l}\text { BUDGET: Medium } \\
\text { CONSULT: } \\
\text { Medium } \\
\text { DRINK: Strong } \\
\text { INCUBATE: Low } \\
\text { INVEST: Low } \\
\text { TECH: Low }\end{array}$ \\
\hline
\end{tabular}

10 - IESE Business School-University of Navarra 


\begin{tabular}{|c|c|c|c|c|}
\hline $\begin{array}{c}\text { Representative quotes for affective sensegiving } \\
\text { (Code denoting affect-laden term in bold: explicit affective term or implicit } \\
\text { through cognitive appraisal theory) }\end{array}$ & $\begin{array}{l}\text { First-order concept } \\
\text { definition }\end{array}$ & $\begin{array}{l}\text { First-order } \\
\text { concept label }\end{array}$ & $\begin{array}{l}\text { Second-order } \\
\text { theme }\end{array}$ & $\begin{array}{l}\text { Evidence } \\
\text { strength }^{*}\end{array}$ \\
\hline $\begin{array}{l}\text { "We celebrated [a successful business transaction] ... [the employees] } \\
\text { were nervous about, are they going to make big change which might } \\
\text { include slashing costs and firing half the people. So you've got to put their } \\
\text { mind at rest...We had somebody from head office in each unit. We gave a } \\
\text { bottle of sparkling wine to each member of staff, and we wrote a letter } \\
\text { which I signed...and then we gave everybody Christmas cards with lottery } \\
\text { tickets in them... not surprisingly that all went down very well." (Founder } \\
\text { BUDGET.) } \\
\text { "We had an evening carting [with one of our big clients] and then we went } \\
\text { to a sort of meal afterwards. But we didn't just take the top level guys. We } \\
\text { took the whole team out. So all different levels of the company. We had a } \\
\text { very good evening. At the end, the guy who had been running the project, } \\
\text { so a pretty senior guy in [the client firm], stood up and he talked about } \\
\text { partnership and how he had experienced something new with CONSULT } \\
\text { that he'd never experienced with any other consulting firm, and the true } \\
\text { meaning of working in partnership, and feeling that you're working } \\
\text { together as a team and that you both have joint responsibilities, and the } \\
\text { fact that CONSULT are constantly there to provide what he needs." } \\
\text { (Founder CONSULT.) }\end{array}$ & $\begin{array}{l}\text { Affective sensegiving } \\
\text { (AS) by organizing } \\
\text { social events in which } \\
\text { founders and venture } \\
\text { stakeholders could } \\
\text { interact with one } \\
\text { another both on a } \\
\text { personal and work } \\
\text { level. Examples: } \\
\text { Going to the bar } \\
\text { together, attending } \\
\text { sports games, having } \\
\text { dinner together. }\end{array}$ & $\begin{array}{l}\text { AS through } \\
\text { paying } \\
\text { customized } \\
\text { attention to } \\
\text { stakeholders' } \\
\text { needs }\end{array}$ & $\begin{array}{l}\text { AS by displaying } \\
\text { personal caring }\end{array}$ & $\begin{array}{l}\text { BUDGET: Strong } \\
\text { CONSULT: Strong } \\
\text { DRINK: Medium } \\
\text { INCUBATE: } \\
\text { Medium } \\
\text { INVEST: Low } \\
\text { TECH: Low }\end{array}$ \\
\hline $\begin{array}{l}\text { "So [an acquaintance and potential employee who had been mugged in the } \\
\text { subway] is sitting in my kitchen telling me this and I just started crying and } \\
\text { crying and crying because it's such a horrible thing, but also because } \\
\text { I've got this weird intuitive sense, I just saw the fragility underneath of } \\
\text { someone who's so strong... On the strength of half of one minute's } \\
\text { conversation on it, she quit her job and said look, I don't know this much } \\
\text { here but I need to stop [working for my current employer] because it's not } \\
\text { working, and l've got this stress on it." (Founder DRINK) } \\
\text { "If somebody calls up and asks me, "Can I spend Thursday home because } \\
\text { I've got the plumber coming in? I want to work from home." [I said], "Not a } \\
\text { problem." We let people work from home whenever it's reasonable to do } \\
\text { so. I think people see that as being a very positive thing. It just generally } \\
\text { makes people feel that we're giving them more responsibility, we trust } \\
\text { them. All these things make people better-humored rather than feeling } \\
\text { that my job is nine-to-five ... People do what they need to do because } \\
\text { they know that we'll be flexible with them when the pressure's not on." } \\
\text { (Founder CONSULT.) }\end{array}$ & $\begin{array}{l}\text { Affective sensegiving } \\
\text { (AS) by dealing with } \\
\text { venture stakeholders } \\
\text { on an individual (as } \\
\text { opposed to group) } \\
\text { level to take care of } \\
\text { their personal well } \\
\text { being. Responding to } \\
\text { the stakeholder's } \\
\text { individual needs by } \\
\text { producing some } \\
\text { customized action } \\
\text { that recognizes these } \\
\text { personal needs. }\end{array}$ & $\begin{array}{l}\text { AS through } \\
\text { paying } \\
\text { customized } \\
\text { attention to } \\
\text { stakeholders' } \\
\text { needs }\end{array}$ & $\begin{array}{l}\text { AS by displaying } \\
\text { personal caring }\end{array}$ & $\begin{array}{l}\text { BUDGET: Strong } \\
\text { CONSULT: Strong } \\
\text { DRINK: Strong } \\
\text { INCUBATE: Low } \\
\text { INVEST: Low } \\
\text { TECH: Medium }\end{array}$ \\
\hline
\end{tabular}




\begin{tabular}{|c|c|c|c|c|}
\hline $\begin{array}{c}\text { Representative quotes for affective sensegiving } \\
\text { (Code denoting affect-laden term in bold: explicit affective term or implicit } \\
\text { through cognitive appraisal theory) }\end{array}$ & $\begin{array}{c}\text { First-order concept } \\
\text { definition }\end{array}$ & $\begin{array}{l}\text { First-order } \\
\text { concept label }\end{array}$ & $\begin{array}{l}\text { Second-order } \\
\text { theme }\end{array}$ & $\begin{array}{l}\text { Evidence } \\
\text { strength }^{*}\end{array}$ \\
\hline $\begin{array}{l}\text { "I think people trust us very quickly because we take an open and honest } \\
\text { approach. You know, it can be on simple things like being a little bit self- } \\
\text { deprecating and actually sort of just being very open and very blunt about the } \\
\text { faults of our organization in areas where we're not going to be as good as some } \\
\text { of the other companies... For example, people will say "Hang on a second, IBM } \\
\text { is a much bigger company than you." Surely there's a lot less risk going with } \\
\text { IBM than there is with little old CONSULT. You can say 'Well yes, that's a } \\
\text { commonly-held view, and yes I would agree with that." (Founder CONSULT.) } \\
\text { "We [told our new employees] it's going to be a big cultural change and we } \\
\text { were clear to them that, you know, they're not going to be judged in the first } \\
\text { five minutes. They're not going to be all lined up against a wall and shot. } \\
\text { They are going to be given the opportunity to develop their business under } \\
\text { the new management, and if they prove that they can do that then they will } \\
\text { all be very successful. So we've been very up front about the cultural } \\
\text { change...Most of them, not surprisingly, have been very, very enthusiastic } \\
\text { and have embraced the change." (Founder BUDGET.) }\end{array}$ & $\begin{array}{l}\text { Affective sensegiving } \\
\text { (AS) by explicitly } \\
\text { addressing (and } \\
\text { sometimes even } \\
\text { emphasizing) the } \\
\text { risks associated with } \\
\text { the venture. }\end{array}$ & $\begin{array}{l}\text { AS through } \\
\text { emphasizing } \\
\text { venture risks }\end{array}$ & $\begin{array}{l}\text { AS by displaying } \\
\text { transparent or } \\
\text { inclusive } \\
\text { organizing }\end{array}$ & $\begin{array}{l}\text { BUDGET: Strong } \\
\text { CONSULT: Strong } \\
\text { DRINK: Medium } \\
\text { INCUBATE: Low } \\
\text { INVEST: Low } \\
\text { TECH: Low }\end{array}$ \\
\hline $\begin{array}{l}\text { "With general managers we have operational reviews every month which } \\
\text { are face-to-face, one-on-one, where we review the financial performance of } \\
\text { the business and we go through any other issues that are outstanding. So } \\
\text { that's the formal communication process. We get together with them every } \\
\text { quarter in advance of their operating review and have a more informal } \\
\text { meeting where we update them on the strategy of the business, and we } \\
\text { have a general open forum with the group, and we sit down and we say, } \\
\text { right, have you got any issues? How are we getting on? Are we delivering } \\
\text { what we said we were going to deliver? How are you feeling about life? } \\
\text { So it's more of a warm and cuddly session." (Founder BUDGET.) } \\
\text { "We had to convince [our strategic partner] that we were going to be good for } \\
\text { our money, that we could raise the money that we needed to raise, which we } \\
\text { were able to do because our bankers are their bankers. So they took some } \\
\text { comfort from that. Could we run the hotels?...We presented to them our } \\
\text { operating plan. I mean, this is what we're going to do with the business. So } \\
\text { what we said to them is sensible and they bought into it." (Founder BUDGET.) }\end{array}$ & $\begin{array}{l}\text { Affective sensegiving } \\
\text { (AS) by performing } \\
\text { management actions } \\
\text { (e.g., with respect to } \\
\text { administration, sales, } \\
\text { operations, } \\
\text { personnel, resource } \\
\text { allocation, investment } \\
\text { accountability) in a } \\
\text { way that involves the } \\
\text { participation of other } \\
\text { relevant people (i.e. } \\
\text { inclusiveness) or can } \\
\text { be observed by } \\
\text { stakeholders (i.e. } \\
\text { transparency). }\end{array}$ & $\begin{array}{l}\text { AS through } \\
\text { displaying } \\
\text { inclusive } \\
\text { organizing }\end{array}$ & $\begin{array}{l}\text { AS by displaying } \\
\text { transparent or } \\
\text { inclusive } \\
\text { organizing }\end{array}$ & $\begin{array}{l}\text { BUDGET: Strong } \\
\text { CONSULT: } \\
\text { Medium } \\
\text { DRINK: Strong } \\
\text { INCUBATE: Low } \\
\text { INVEST: Low } \\
\text { TECH: Medium }\end{array}$ \\
\hline
\end{tabular}

\section{* Table entries in last column:}

"Strong" - Evidence from founder interviews, as well as confirmation by stakeholders.

"Medium" - Evidence either from founder interviews, or from stakeholders (but not from both).

"Low" - No evidence from founder interviews or from stakeholders. 
Table 2 depicts our analysis of founders' affective sensegiving actions independent of their outcomes, i.e., whether these actions had positive, neutral or negative consequences for the firm. It summarizes our main findings, which we will explain next.

\section{Findings}

We found that affective sensegiving actions generally helped young organizations to mobilize resources. According to our data, resource mobilization encompasses both personal discretionary support and collective support from stakeholders. Discretionary actions are distinct from transactional ones in that the former are largely voluntary and a priori unspecified. They are neither formally nor implicitly contracted. Examples of discretionary support from stakeholders include unexpected offers from potential investors to provide equity finance, or ideas about product development from employees who were not hired for that role.

As shown in Table 2, our data suggest three types of affective sensegiving action that are aimed at influencing stakeholders' interpretation and that help mobilize resources for the young firm. We found significant differences among founders with regard to how they used these actions. We now focus on the presentation of those data that a) showed how we inductively derived the various affective sensegiving action categories, and b) suggest a causal link between affective sensegiving and resource mobilization.

\section{Affective Sensegiving by Displaying Socially Valued Entrepreneurial Characteristics}

Founders play a central role in building new businesses, as Jordi, a consultant for DRINK, explained: "Everything revolves around [the founders]: their ego, their insecurities, their ambitions." In these founder-centric environments, some of their actions attempted to elicit stakeholders' positive affect by displaying socially valued entrepreneurial characteristics such as entrepreneurial background and achievements; socially desirable entrepreneurial attitudes such as total commitment and high personal energy; and certainty-related emotions such as passion, excitement, contentment, calm, anger or contempt. These emotions convey an individual's psychological state of confidence, conviction, commitment or devotion to an entity or situation (Cardon et al., 2009; Tiedens and Linton, 2001; Pelzer, 2005).

For example, Christine, the founder of DRINK, described how she addressed a private investor's strong initial reluctance to making a financial commitment by explicitly acknowledging his achievement in creating his own venture and deliberately drawing parallels to her own situation. That is, her sensegiving about her own entrepreneurial situation and her request for finance were associated with a strong appeal to the investor's pride and empathy with entrepreneurial ambition:

"He said, "I'm still not sure that you're going to deliver." I said, "Yes, you're right, but you started with three people three years ago - that's all I'm doing. I've got the same drive, so do you recognize that in me?" That very quickly went to the heart of this person's identity, which is, he was hugely proud of having built up this thing in three years." (Founder DRINK. Emotions associated with sensegiving: empathy because invoking common situation, and pride of achievement.)

Note that the investor remained skeptical about the founder's ability to deliver business results after Christine's factual presentation of her new venture. Christine felt compelled to add affect- 
based arguments to the cognitive ones to sway the investor's decision. She noted, "That's what clicked. The next morning, he was trying to buy me and the team. So it changed that fast. From being 'Who the hell are you?' to, 'Are you up for sale?'”. Research on social persuasion corroborates the likely effectiveness of such a tactic: that is, arguments that combine similarity and praise generate liking in return, and the recipient's willingness to comply with the wishes of the person offering the praise (Cialdini, 2001).

Socially valued entrepreneurial characteristics can also include specific emotional displays, such as passion, enthusiasm or calm. Our data suggest that venture founders' attempts at influencing stakeholders' perceptions indeed sometimes included displays of these emotions. Such affective sensegiving was quite persuasive and produced desired resource mobilization effects. Christine, the founder of DRINK, pointed to the important role of displaying enthusiasm in her attempt to convince a veteran expert and entrepreneur in the whisky industry to join her nascent distillery venture:

"So I met this guy who had set up the same thing in Wales. I just said, this is what I'm thinking of doing, and I don't know anything about this but I'm going to give it a go. You've just built one, and you're now successful. So how would you like to be involved? He was just wowed by the whole thing. I think he liked my enthusiasm...he was completely wowed, he recognized a lot of what I was saying was similar to the fun and drive that he'd had building this first distillery two years ago." (Founder DRINK. Emotions associated with sensegiving: enthusiasm, liking, awe, fun in building a new business.)

Christine displayed enthusiasm as part of her effort to get the expert on board, elicited his liking and awe, and reminded him about the fun of building his first venture. One of her employees confirmed the effectiveness of Christine's emotional displays. She explained that, "Christine's enthusiasm was contagious [... ] so you couldn't help but actually listen to her and think yeah, oh my gosh, she's right. Everyone was sharing her enthusiasm and wanted to get the company going."

Interestingly, our data suggest that emotional displays could also work well as part of the founders' influencing of external stakeholders who work in seemingly unemotional and rulebound institutions, such as governments: "The government had to select British companies for their funding, and they gave it to us, [based on] the criteria that we seemed to be working so hard and they felt that our enthusiasm would [make] the innovation work" (founder DRINK). Somewhat surprisingly, displays of negative emotions such as anger and annoyance could produce a similar effect. When the co-founders of TECH, for example, were raising funds in the early days of their venture, they "would get outright annoyed if people challenged us about it not being a go. So we signaled this amazing belief that we knew what we were doing," and this helped them win financial support, as Phil (founder TECH) told us.

Adjacent literatures corroborate our finding on the importance of certainty-related emotions for decision-making under uncertainty (Cardon et al., 2009; Smith and Ellsworth, 1985). Lab experiments suggest that, compared to emotions associated with uncertainty such as fear and hope, certainty-related emotions resulted in greater reliance on the expertise of a source of a persuasive message (Tiedens and Linton, 2001). Elsbach and Kramer (2003) showed that decision-makers in the uncertain business of movie production tend to assess as creative and committed those screenwriters who are demonstrably passionate about selling their script. Displaying certainty-related emotions can create a perception of ability, which constitutes one dimension of trustworthiness. 


\section{Affective Sensegiving by Displaying Personal Caring}

Our data show, furthermore, that founders' influencing actions could include affect when the founders showed personal caring for stakeholders. This could be achieved by organizing energizing events for stakeholders or by paying customized attention to their personal needs. When founders and stakeholders go out to restaurants or bars together, for example, or attend sporting events or concerts, they move their connection to a more personal level and augment the closeness of their business relationships. These informal interactions, initiated by founders, were intended to be energizing experiences, aimed at evoking high-activation emotions like fun, excitement and joy. John, an employee of CONSULT, confirmed the invigorating relationships that employees had developed with their managers as a result of these energizing events. "Just going out for an evening with Sam [the co-founder], it's great fun." He further elaborated on Sam's often spontaneous influencing actions to elicit joy and fun among the members of the young firm: "One day when we just won a contract ... Sam just disappeared off and came back with a crateful of beer and just bonked it on the desk and told everyone to stop working and have fun and celebrate." Although such actions may seem obviously useful, not every entrepreneur in our sample used them. Alex, a former partner of INVEST, for example, complained that in his firm, "so very little time was spent celebrating successes."

Affective sensegiving that involves celebrating successes and organizing and attending energizing events can lead to resource mobilization. For instance, it can foster the informal and spontaneous sharing of ideas to develop new products. According to Sam, the founder of CONSULT, the fun elicited through energizing events "makes people feel like they're really part of what's going on. They can come and talk to us, genuinely, about how the firm is doing. Hey, I had a great new idea for a new product - what do you think about this?" Affective sensegiving may also be useful with other stakeholders, such as clients. As Sam explained: "You take [clients] to a football match and all of a sudden you have something in common. The relationship takes on a very different angle... we've got a very loyal set of clients." This is crucial, because cash-flow negative fledgling organizations depend on the loyalty of paying customers. The persuasion literature corroborates the likely effectiveness of such a persuasion tactic: that is, identifying real similarities and expressing genuine appreciation for them can generate liking in return, and increase the recipient's propensity to satisfy the wishes of the person appreciating these similarities (Cialdini, 2001).

Beyond organizing collective energizing events, the founders in our study aimed at eliciting stakeholders' positive affect (e.g., fun, joy, liking) as part of their influencing efforts by personalizing the attention they paid to individual stakeholders. According to Sam, "fun is not just humor. It is making sure people enjoy what they do." To create joy and engagement at work, Sam would tell employees (i.e., consultants): "If you have a problem, you know you have a whole organization here to help you out with it, whether this is professional or otherwise we will be there...there are things we can help out with. Tell us about, get us involved, let us know what we can do." In a similar vein, James, the founder of BUDGET, made a deliberate effort to travel and talk to all their hotel managers to find out about their individual problems and help resolve them.

"You know, going around... It's a pain because it's a lot of traveling over a very short period of time. But delivering on your promise is important. Secondly, just being there and talking to them because they then start to treat you as an individual, rather than simply as the bloke who runs the business. You talk to them as a colleague, rather than 
right, it's hierarchical. This is what you do." (Founder BUDGET. Emotion associated with sensegiving: sympathy)

Sympathy is implied in how the founder engaged respectfully with his middle managers, treating them all as individuals with distinct attributes rather than commanding generic employees. Sevin, a middle manager of BUDGET, confirmed the founders' personal caring actions: "They want to hear from us, they want to know how we are. They want to make sure that we're all right and that we haven't got any problems." The founders' attention to his personal needs made him "comfortable" and "happy" to work for the company and mobilized his support for the new firm: "I've always been very supportive of the company... it is an excellent company to work for."

By contrast, when resources at TECH became tight a few years after founding, the entrepreneur did the exact opposite of caring for peoples' personal needs. According to one top executive, the founder "shouted down [the employees] in front of their fellow staff members, which is a very demoralizing thing to do." Public displays of anger at TECH hurt employees' feelings and nurtured the image of a "dictatorial" rather than benevolent leader, which negatively affected employee motivation and initiative. This finding is corroborated by research that shows that leaders' affect can be contagious to their followers, and the group' s affect then influences their task-related behaviors (e.g., Sy, Côté, and Saavedra, 2005).

The literature supports our findings on the benefits of generating positive feelings during social exchanges. These feelings influence affective attachment and liking for the people involved (Lawler, 2001). Positive affect tends to promote attributions of positive motives and reduce interpersonal conflict (Barsade, 2002) while negative affect does the reverse (Forgas, 2000). Affective attachment fosters cooperative tendencies in repeated exchange relationships, even in the light of attractive alternatives (Lawler and Yoon, 1996). People in positive affective states see a larger range of stimuli and process information in a more flexible fashion than people with negative states (Fredrickson, 1998), and this enhances creativity (Isen, Daubman, and Nowicki, 1987) and performance of complex tasks (Staw and Barsade, 1993).

\section{Affective Sensegiving by Displaying Transparent or Inclusive Organizing}

Our data also suggest that founders' influencing of stakeholders could involve affect when the founders showed transparency in their operations. We found, for example, that founders' sensegiving to prospective investors and employees included emphasizing potentially fearsome business risks; but rather than deterring skeptical stakeholders, this approach helped mobilize resources from them. The founder of CONSULT, Sam, explained that he had emphasized the risks of his venture to candidates for positions in his young firm, and was surprised by their readiness to join:

"In recruiting, the more you try to push people away, the more they want to get involved. Absolutely phenomenal. We tell people what we do and say yes, you know, this is really exciting stuff, but let's tell you about the downsides, and boy, there are some downsides. We could really screw up on this, we could really screw up on that...there are real risks involved." (Founder CONSULT. Emotions associated with sensegiving: excitement, fear.)

Transparency here involves reference to the potential excitement of working in the venture, with a simultaneous emphasis on the downside risks and potential losses to be feared. Sam had also emphasized the risks of his planned venture to private investors, once again with quite 
surprising results: “The more that I said, 'Oh, but there's risk. Oh it's a bit dodgy. I don't want to lead you astray, guys...', the more I tried to push them off... the more they liked it." Roman, a private investor, confirmed this approach, as well as its effectiveness at mobilizing resources: "We've all made investments because we wanted to make the investment. We weren't badgered into making an investment. In fact, we were actively encouraged not to invest." Our data suggest that founders' affective sensegiving through transparent organizing elicited support from potential stakeholders.

Although Cialdini (2001) has noted the benefits of using "downsides" or "scarcity" in persuading others, we were still intrigued to find that this also seemed to work in an entrepreneurship context. We had assumed that founders would be more likely to emphasize their ventures' upsides and tone down references to any downsides 1) to increase stakeholders' comfort in the firm, 2) because this might be expected from entrepreneurs who are prone to overconfidence (Busenitz and Barney, 1997), and 3) because it could be counter-productive to emphasize risks when stakeholders are already nervous.

James, the founder of BUDGET, took a more indirect approach to transparency, and sensegiving. Rather than directly pointing out potential risks to investors, he supplied all necessary information (e.g., showed them around existing operations and shared the business plan) to let them form their own impressions about the venture's downsides. His sensegiving aimed at eliciting the investors' comfort, an emotion that is associated with the formation of a trustful relationship (Edmondson, 1999, 2004):

"We took them around our hotels, we showed them what we do. They were comfortable with that. We took them through our operating plan and, again, they were very comfortable with that. So consequently, I think those two things combined gave them the comfort that we can do what we say we can do." (Founder BUDGET. Emotion associated with sensegiving: comfort about the organizing actions of the founders.)

By being transparent and inclusive, James also calmed nervous and worried employees who had recently joined from a larger and more established hotel chain. His inclusive organizing involved enacting management actions (e.g., with respect to sales, operations, personnel or resource allocation) in ways that encouraged the stakeholders' participation. Specifically, James assuaged new employees' concerns by involving them in projects that gave them an opportunity to actively shape their future.

We've started to set up project teams to do things. One of the things they've said is look, we need to think about uniforms. So we said okay, fine, two of you as general managers are now responsible for thinking about new uniforms. We've put another project team together to simplify and restructure food and beverage. So you start to get them involved. That's one way of dealing with nervousness." (Founder BUDGET. Emotion associated with sensegiving: nervousness.)

Giving new employees the opportunity to take ownership of business projects reduced their nervousness and paid off in resource mobilization benefits. James, the founder, mused that "when the employees see that they're not going to get beaten up then they start to relax. Then they start to open up and they start being more confident about expressing their ideas." Put differently, the founders' affective sensegiving through transparent or inclusive organizing elicited employees' feelings of calm and comfort, which represent positive low activation emotions (Larsen and Diener, 1992) that reduce nervousness, and led to resource mobilization (in this case, the suggestion of new ideas). 
Employees indeed responded positively (and affectively) to the founder's efforts to include them in the decision-making. One middle manager, Nelson, commented: "[James] engenders a sort of cooperative spirit, and he involves you in his venture, makes you want it to succeed... that does give me hope in the future." In other words, the founder's inclusive management actions elicited a positive emotion (hope) in the manager. In another case, Christine, the founder of DRINK, believed that "when you are dealing with people in a straightforward way, there's a sense of almost moral edge. You attract people like that." She went on to explain how her behavior should foster trust among her colleagues:

"I can see something of substance before others, and then I put some structure and solidity to it and allow other people to look at it. I am extremely honest and direct. So I say exactly what it is... People know that if you say you're going to do something, something's going to happen, and they also trust you... [They] think not only will it be fun, you know, but I'm not going to rip them off. As [one of my collaborators] said to someone who wasn't sure they were going to get paid: "I have known Christine for five years. She will never not pay your bill. She will go bankrupt before she doesn't pay your bill.” (Founder DRINK.)

According to Christine, her sensegiving to others based on transparency and inclusiveness (giving her a "moral edge") not only elicited (the expectation of) fun as an emotion in other people, but it also built their trust in her. That trust, then, likely represents a crucial linchpin between the founder's affective sensegiving and the resulting resource mobilization benefits. We will elaborate further on this trust-based mechanism in a later section where we analyze the stakeholders' interpretations of founders' actions.

The adjacent literatures on emotions and organizational change corroborate our findings on the benefits of generating quiescent emotions, characterized by pleasant, low activation feeling states such as comfort, security and calm (Larsen and Diener, 1992) in organizational contexts in which people feel threatened, unsafe or insecure (Huy, 2002). Feeling psychologically safe from perceived interpersonal risks in their work environment helps people overcome defensive behaviors that hamper learning from one another (Edmondson, 1999).

In contrast, in some of the firms we studied, members seemed more engaged in opaque, behindthe-scenes moves (e.g., building secret political coalitions). Such actions reduced trust. Phil, the founder of TECH, for example, tried to prevent a particular venture capitalist from joining the board of directors, which led to continuous tensions at the board level and negatively affected resource mobilization. Phil commented: "Unfortunately, he ended up being on the board anyway, and he was aware that we had vetoed his idea of being a board member. So there was tension happening, which wasn't great."

As mentioned earlier, beyond these three types of affective sensegiving actions - displaying socially valued entrepreneurial characteristics, personal caring, and transparent or inclusive organizing - we also found evidence that founders used brinkmanship tactics, aggression, and threat to secure benefits for their ventures. We describe these actions in Appendix A.

\section{From Founders' Affective Sensegiving to Resource Mobilization from Stakeholders}

The micro-evidence shown above based on individual codes from founders suggests a close association, if not a causal link, between affective sensegiving and resource mobilization outcomes. To further confirm this finding, we performed a qualitative analysis of the overall level of resource mobilization in our six firms. This analysis is summarized in Table 3 (Panels A and B). 


\section{Table 3}

Panel A: Resource Mobilization: Qualitative Assessment and Representative Quotations

\begin{tabular}{|l|l|l|l|}
\hline & \multicolumn{1}{|c|}{ BUDGET } & \multicolumn{1}{|c|}{ CONSULT } & \multicolumn{1}{|c|}{ DRINK } \\
\hline $\begin{array}{l}\text { Resource } \\
\text { Mobilization }\end{array}$ & $\begin{array}{l}\text { Strong } \\
\text { "I suggested a few things...and you know, } \\
\text { the [founders] said let's do it." (Nelson, } \\
\text { Middle Manager) } \\
\text { "You can get people to do things when they } \\
\text { wouldn't normally want to do them." (Peter, } \\
\text { Co-founder) } \\
\text { "We get on with it and find a solution...It's } \\
\text { about how can we all get together and make } \\
\text { it a bit better." (Ruth, HR Manager) }\end{array}$ & $\begin{array}{l}\text { Strong } \\
\text { "The industry suddenly collapsed. We } \\
\text { decided as senior managers to go out and } \\
\text { get involved in projects because we didn't } \\
\text { have many employees and needed to bring } \\
\text { revenue in." (Lorenzo, Senior Manager) } \\
\text { "There's a lot of us that joined at the start } \\
\text { that are still left, and it hasn't been a great } \\
\text { deal of turnover." (Employee) }\end{array}$ & $\begin{array}{l}\text { Strong } \\
\text { "I've since been asked to sit on two other } \\
\text { good, and I think long-term will bear a lot of } \\
\text { fruit... There've been articles in the Financial } \\
\text { Times." (Christine, Founder) } \\
\text { "Everyone has the opportunity to contribute, } \\
\text { and that makes a phenomenal difference to } \\
\text { my motivation to the company." (Josephine, } \\
\text { Finance Director) }\end{array}$ \\
& & \\
\hline
\end{tabular}

Table 3

Panel B: Resource Mobilization: Qualitative Assessment and Representative Quotations

\begin{tabular}{|l|l|l|l|}
\hline & \multicolumn{1}{|c|}{ INCUBATE } & \multicolumn{1}{|c|}{ INVEST } & \multicolumn{1}{|c|}{ TECH } \\
\hline $\begin{array}{l}\text { Resource } \\
\text { Mobilization }\end{array}$ & $\begin{array}{l}\text { Weak } \\
\text { "We didn't feel we could realistically go } \\
\text { back to our shareholders and ask for more } \\
\text { money until we'd sorted out what we } \\
\text { got...We got a fairly direct [negative] } \\
\text { response from our shareholders." (Kurtis, } \\
\text { Co-founder) } \\
\text { "The employees were people working in } \\
\text { the warehouse...They were more like } \\
\text { workers in a factory." (Susan, Spouse of } \\
\text { Founder) }\end{array}$ & $\begin{array}{l}\text { Weak at first, then moderate } \\
\text { "[The partners] were all concerned to protect } \\
\text { their interest. So they got very personally } \\
\text { protective and individually greedy." (Alex, } \\
\text { Former CEO and Director) } \\
\text { "The managers] were still behaving at the end } \\
\text { as they were at the beginning, individually. So } \\
\text { you have...their individual politicking." (Alex, } \\
\text { Former CEO) }\end{array}$ & $\begin{array}{l}\text { Strong at first, then weak } \\
\text { AT FIRST: "We didn't get any [skilled } \\
\text { engineers] turning down our job offers. Not a } \\
\text { single one." (Patrick, Founder) } \\
\text { "We asked people to defer salary. People } \\
\text { turned back and wanted to defer actually } \\
\text { more." (Patrick, Founder) } \\
\text { THEN: "We do not have at the moment a true } \\
\text { customer." (Kevin, Co-founder) } \\
\text { "There was resignation among the } \\
\text { employees." (Jim, new CEO) }\end{array}$ \\
\end{tabular}


Juxtaposing panels A and B of Table 3 with Table 2 allows us to see that firms in which founders used a variety of affective sensegiving actions (BUDGET, CONSULT, DRINK) also achieved high levels of resource mobilization (Panel A of Table 3), whereas those in which founders used little, if any, affective sensegiving (INCUBATE, INVEST, TECH) only achieved low levels of resource mobilization (Panel B of Table 3). This is consistent with, but does not strictly imply, a linear relationship between affective sensegiving and resource mobilization. First, some affective sensegiving actions may not have discernible effects at the firm level; their effect may be contingent on other factors, or they may even lead to undesired outcomes, as we will show later in this section. Second, firms that favor a cognitive-rational approach and use few affective sensegiving actions can also mobilize adequate resources. This is particularly true when firms operate in predictable, resource-rich environments.

Our data support this nuance: All six firms in our sample were reasonably successful in their early days, in and around the year 2000, which was a time of high environmental munificence (Zott and Amit, 2007). They managed to acquire vital resources, such as paying customers (with the exception of DRINK and TECH, who focused initially on R\&D), highly qualified employees and sufficient external funding, so that they could begin developing products and building operations. But then the environment changed drastically to one of low munificence, and all founders had greater difficulty in acquiring new resources to ensure the firms' survival and growth. It was at that point that differences in resource mobilization began to emerge, differences that can be explained in part by the founders' differing propensity to engage in affective sensegiving. In other words, affective sensegiving seems to foster resource mobilization more strongly under conditions of high uncertainty and low munificence. These conditions, therefore, represent moderators of the theorized positive association between affective sensegiving and resource mobilization in young firms. ${ }^{1}$

\section{Stakeholders' Affective Interpreting}

As shown above, the data we collected from founders between February 2002 and February 2005 suggest that their affective sensegiving helped with resource mobilization from stakeholders. It also hints at a potential explanation, namely trust-building with stakeholders. To examine - from stakeholders' perspectives - whether founders' affective sensegiving actions actually foster trust-building, which then facilitates resource mobilization, we analyzed stakeholders' interviews (conducted between mid 2005 and early 2006, after we had talked to the founders). As shown below, our analysis not only confirmed our conjecture that founders' affective sensegiving helps resource mobilization through trust-formation but it also corroborated the three types of affective sensegiving action categories we found. Stakeholders indeed interpreted 1) founders' socially valued entrepreneurial characteristics; 2) founders' personal caring, and 3) founders' transparent or inclusive organizing. Thus, we noted a close alignment between founders' affective sensegiving and associated stakeholders' interpretations. For example, Fred, the chairman of BUDGET's board of directors, explained his involvement with the young company by referring to James' (the founder's) entrepreneurial characteristics. He depicted James as “a very likeable individual. He’s a very clear thinker. His business plan

\footnotetext{
${ }^{1}$ This is consistent with theoretical reasoning. Under conditions of complete factual and reliable information and high predictability between causes and outcomes, affect likely displays a weak effect in comparison to cognition in influencing stakeholders' resource mobilization. Affect likely has a stronger effect when stakeholders are uncertain about the odds of success of the new firm and the real abilities of the founders. In environments of low economic munificence, stakeholders likely perceive a higher level of uncertainty about startups' odds of success.
} 
was well put together." Fred's resource mobilization resulted from his interpreting the founder's valued abilities, associating affect (liking) with cognition (ability to think clearly and devise a good business plan). We construe this interpretation process of associating affect and cognitive assessment as affective interpreting.

Affective interpreting of founders' socially valued entrepreneurial characteristics. As we explained earlier, these socially valued characteristics include background and achievements (e.g., having put together a well thought-out business plan), commitment, personal energy and certainty-related emotions. For example, Andrew, BUDGET's lawyer, described the founder's entrepreneurial characteristics in terms of his calm composure:

"[James] is a very calm person and very measured ... so he impresses people a lot. He's the sort of person people want to like, but in quite a reserved way... He conducts himself at all times in a very calm way, which makes doing business with him quite pleasurable." (Lawyer BUDGET. Emotions associated with interpreting: calm, liking, pleasure.)

In what sense is calmness socially valued? Jordi, an independent industry expert dealing with DRINK, drew a comparison between a "good" founder and a duck: "You must be calm on the surface but paddling furiously underneath. You must assure an outward calm motion to the people around you because they're watching your body language." The words of Andrew, BUDGET's lawyer (it makes "doing business with him ... pleasurable") support the resource mobilization benefit of such affective interpreting: the founder's calm composure increased resource holders' propensity to interact with him.

Our data suggest, furthermore, that trust-formation can help explain the positive effect of affective sensegiving (by the founder) and interpretation (by the stakeholder) on resource mobilization for the venture. Joshua, the CFO of BUDGET, confirmed that, as time progressed, the investors "trust us more... you build up a relationship, and you build up certain trust." Trust-building was also reported at employee level. Ruth, BUDGET's HR director, explained that the employees and the founders "do trust each other. But trust comes over a period of time, and we are only beginning to establish that real trust, and this is understandable. You just don't trust somebody as soon as they come to work for you." And Andrew, the lawyer of BUDGET, told us that the founder's charm (affect) combined with his sales skills (cognition) increased investors' confidence in the venture: "This personal style is very charming and [James and his co-founder] sell their product well. I think that makes investors feel very comfortable... it facilitates the good of the company." Although charm could be considered a passive personality attribute, one can also actively charm others to elicit their liking and comfort.

The adjacent literatures corroborate the association between the affective state of feeling "comfortable" and trust-building. Russell and Pratt (1980, p. 312) describe feeling "comfortable" as having moderately high level of pleasantness with moderately low arousal, and consider comfort as a quiescent emotion (i.e., with pleasant, low activation affect) that is close to other emotional states such as feeling at ease, calm, or relaxed (also see Feldman Barrett and Russell, 1998). The Oxford English Dictionary defines one of the meanings of comfortable as feeling confident and not worried or afraid. Comfort is likely to be elicited by appraisals of no harm in interpersonal interactions or little uncertainty in negative outcomes (Kahn, 1990). The positive affect that characterizes comfort promotes attributions of positive motives to other people, while negative affect elicits attributions of negative motives (Forgas, 2000). Feeling comfortable in social interactions should facilitate and/or indicate trust formation (Edmondson, 2004; Williams, 2007). 


\section{Table 4}

Stakeholders' Affective Interpreting

\begin{tabular}{|c|c|c|c|}
\hline & BUDGET & CONSULT & DRINK \\
\hline $\begin{array}{l}\text { Interpreting } \\
\text { Socially Valued } \\
\text { Entrepreneurial } \\
\text { Characteristics }\end{array}$ & $\begin{array}{l}\text { Ruth (HR Director): "[James is] very } \\
\text { enthusiastic about the business, which gives } \\
\text { me a lot of comfort... now l'm starting to } \\
\text { establish that psychological attachment to } \\
\text { the organization." } \\
\text { Valued characteristic: enthusiasm. } \\
\text { Emotions associated with interpreting: } \\
\text { comfort, which indicates trust-building; also } \\
\text { attachment to the new firm. } \\
\text { Andrew (Lawyer): "In emotional highs and } \\
\text { lows, James is this very calm, constant } \\
\text { person. I've dealt with other people in } \\
\text { business who clearly do veer from one } \\
\text { extreme to the other, completely the } \\
\text { opposite of how James deals with things. } \\
\text { The occasional moments that he looks as if } \\
\text { he's under pressure, he still maintains his } \\
\text { basic calm. He ticks away. That's the } \\
\text { interesting thing about him... He develops } \\
\text { his team as friends and with loads of } \\
\text { personal trust." } \\
\text { Valued characteristic: calmness under } \\
\text { pressure. } \\
\text { Emotion associated with interpreting: } \\
\text { calmness, suggesting trust-building. }\end{array}$ & $\begin{array}{l}\text { Roman (Angel Investor): "I've known Sam as } \\
\text { a friend for a very long time...I made that } \\
\text { investment, you know, because I believed in } \\
\text { him and liked him and thought he would do a } \\
\text { good job." } \\
\text { Valued characteristic: ability to do a good } \\
\text { job. } \\
\text { Emotion associated with interpreting: liking. } \\
\text { John (Employee): "I think [the founder's] } \\
\text { decision-making has always been very } \\
\text { sound, and that gives me a lot of hope for } \\
\text { the future... actually a lot of times he knows } \\
\text { more than I do. So that fills me with } \\
\text { confidence." } \\
\text { Valued characteristics: sound decision- } \\
\text { making, superior knowledge. } \\
\text { Emotions associated with interpreting: hope, } \\
\text { confidence, suggesting trust-building. }\end{array}$ & $\begin{array}{l}\text { Barbara (Employee): “I decided to buy some } \\
\text { shares. I believe in the company being } \\
\text { successful in the future, and that's because I } \\
\text { saw how Christine, Theresa, and Josephine } \\
\text { as well, how much they were putting into the } \\
\text { company. I would say it's more than their } \\
\text { life. And they're good at what they're doing. } \\
\text { So that's what I think gives hope about the } \\
\text { future of the company: their involvement and } \\
\text { their professionalism.” } \\
\text { Valued characteristics: total commitment and } \\
\text { effort, ability to do a good job. } \\
\text { Emotion associated with interpreting: hope. } \\
\text { Jordi (Industry Expert): "I think Christine } \\
\text { gives the image of craziness. But I don't } \\
\text { think she gives the image of panicking. } \\
\text { Somehow she's quite confident that we will } \\
\text { succeed. So she's very positive in her } \\
\text { attitude. And she's got some very good } \\
\text { people." } \\
\text { Valued characteristics: calmness, optimism. } \\
\text { Emotions associated with interpreting: } \\
\text { calmness. }\end{array}$ \\
\hline $\begin{array}{l}\text { Interpreting } \\
\text { Personal Caring }\end{array}$ & $\begin{array}{l}\text { Ruth (HR director): "What makes me feel } \\
\text { comfortable working for this venture,] I think, } \\
\text { is the relaxed environment. It's knowing that } \\
\text { people do value what I have to say, that I am } \\
\text { trusted, that the things I do are appreciated... }\end{array}$ & $\begin{array}{l}\text { John (employee): “I think most people that } \\
\text { you speak to in CONSULT say I really enjoy } \\
\text { working for CONSULT because it's a small } \\
\text { company, we're very similar people who like } \\
\text { having fun. We don't get paid badly but we }\end{array}$ & $\begin{array}{l}\text { Rupert (employee): "Christine gets the right } \\
\text { people and gets people that really love what } \\
\text { they do... there is a really strong feeling of } \\
\text { community within the company, it's almost } \\
\text { like working with siblings. I think that's a very }\end{array}$ \\
\hline
\end{tabular}

22 - IESE Business School-University of Navarra 
Table 4 (continued)

\begin{tabular}{|c|c|c|c|}
\hline & BUDGET & CONSULT & DRINK \\
\hline & $\begin{array}{l}\text { those sorts of things are important. I think } \\
\text { some acknowledgements of the level of } \\
\text { effort a lot of the people in the company put } \\
\text { into the business - a lot of people are } \\
\text { working a lot of hours." } \\
\text { Personal caring: valuing and acknowledging } \\
\text { the contributions of individual employees. } \\
\text { Emotions associated with interpreting: } \\
\text { relaxation, comfort, suggesting trust-building. } \\
\text { Andrew (lawyer): "So we just went off and } \\
\text { celebrated at a casino. It was just having } \\
\text { fun. What they want to do is operate their } \\
\text { business as friends, having fun." } \\
\text { Personal caring: celebrating success with } \\
\text { employees. } \\
\text { Emotion associated with interpreting: fun. }\end{array}$ & $\begin{array}{l}\text { don't get paid exceptionally well. But we } \\
\text { have fun. We do feel that we're listened to. } \\
\text { We do feel that there's still a good future for } \\
\text { the company and that, you know, we've } \\
\text { merely delayed our income rather than it's } \\
\text { never going to happen. I just genuinely think } \\
\text { that people are very motivated because } \\
\text { they're respected and they have fun." } \\
\text { Personal caring: listening to employees, } \\
\text { treating them respectfully, enabling fun. } \\
\text { Emotions associated with interpreting: fun, } \\
\text { hope. }\end{array}$ & $\begin{array}{l}\text { important thing, and that really draws you } \\
\text { into the company and makes it attractive and } \\
\text { comfortable to work with, and secure". } \\
\text { Personal caring: selecting new employees } \\
\text { carefully based on their personal needs and } \\
\text { fit with the existing members of the firm. } \\
\text { Emotions associated with interpreting: love, } \\
\text { comfort, suggesting trust-building. } \\
\text { Barbara (employee): "I was happy with the } \\
\text { top management team being family- } \\
\text { like...I felt comfortable because I thought I } \\
\text { could actually rely on people. When I had a } \\
\text { problem I could speak to them and it would } \\
\text { get sorted somehow." } \\
\text { Personal caring: taking care of employees' } \\
\text { individual problems. } \\
\text { Emotions associated with interpreting: } \\
\text { happiness, comfort, suggesting trust- } \\
\text { building. }\end{array}$ \\
\hline $\begin{array}{l}\text { Interpreting } \\
\text { transparent or } \\
\text { inclusive } \\
\text { organizing }\end{array}$ & $\begin{array}{l}\text { Sevin (middle manager): "Looking at [the } \\
\text { founders'] approach to management and } \\
\text { dealing with people has made me a lot more } \\
\text { relaxed. I think in the past, running a very } \\
\text { busy unit, very busy hotels, I've probably not } \\
\text { handled problems as well as I could have } \\
\text { done, and I found it very stressful. Now, } \\
\text { working with James... has made me a lot } \\
\text { more relaxed. I thoroughly enjoyed my job } \\
\text { over the last three years more so than I have } \\
\text { done over the last } 25 \text { years. So it's been } \\
\text { fantastic." } \\
\text { Transparent or inclusive organizing: } \\
\text { revealing management techniques to lower- } \\
\text { level managers. } \\
\text { Emotions associated with interpreting: } \\
\text { relaxation, stress, joy. }\end{array}$ & $\begin{array}{l}\text { John (employee): "[ln terms of our] financial } \\
\text { difficulties, [the founders] had given us } \\
\text { enough information to allow us to know that } \\
\text { we needed to do something different, but not } \\
\text { given us the complete story in terms of } \\
\text { making a lot of people worried about the } \\
\text { potential, you know, loss of jobs and } \\
\text { things... I think they told us just enough for } \\
\text { us to be concerned but not too much for us } \\
\text { to be so worried that we kind of deserted." } \\
\text { Transparent or inclusive organizing: } \\
\text { revealing details about the venture's } \\
\text { financial situation to employees. } \\
\text { Emotions associated with interpreting: worry, } \\
\text { concern. }\end{array}$ & $\begin{array}{l}\text { Josephine (employee): "Christine said I think } \\
\text { I want to build a distillery [in a remote area], } \\
\text { which is just the maddest idea, and would I } \\
\text { like to be involved. I was yeah, right, sounds } \\
\text { like a good idea. And that is how I got into } \\
\text { the mad adventure, really. I've given up my } \\
\text { accounting practice pretty much, and there's } \\
\text { actually none of that left, and l've gone into a } \\
\text { business where I feel completely a part of." } \\
\text { Transparent or inclusive organizing: } \\
\text { revealing daring startup plans. } \\
\text { Emotion associated with interpreting: } \\
\text { madness (connotation: adventurous, } \\
\text { thrilling). } \\
\text { Rupert (employee): "Christine is an } \\
\text { immensely interesting person to sit and talk } \\
\text { with... I mean, the company as a whole is }\end{array}$ \\
\hline
\end{tabular}


Table 4 (continued)

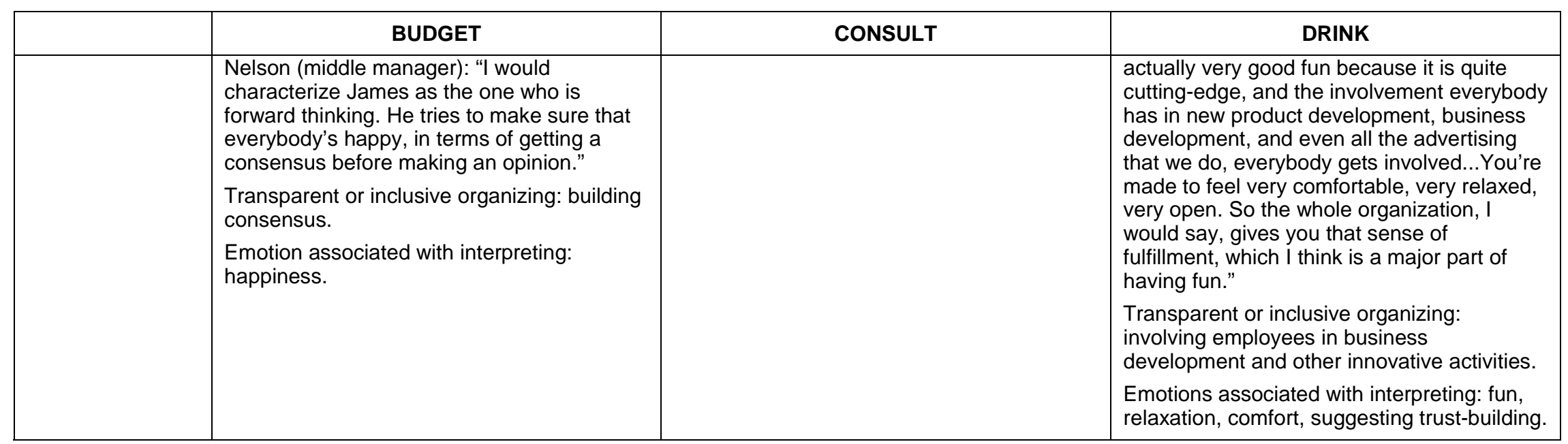


Table 4 shows how stakeholders interpreted affective sensegiving actions that invoked founders' entrepreneurial characteristics and how this led to trust-building and facilitated resource mobilization. By combining evidence from founders' affective sensegiving actions (see Table 2) and stakeholders' affective interpretation of their actions (Table 4), we can infer that this type of affective sensegiving is likely to create stakeholders' perceptions that the founder is competent to build a successful business. Indeed, founders who display valued entrepreneurial characteristics are more likely to create stakeholders' perception that they have the necessary abilities to build startup firms successfully in comparison to other founders who fail to show the entrepreneurial attributes that vigilant stakeholders expect to see.

Affective interpreting about founder's personal caring. Founders' personal caring actions include organizing energizing events for stakeholders (such as celebrating success or going out to together). Randy, a mentor and advisor to CONSULT, described the effect that such actions had on employees:

"I've been out for a drink with Sam and his employees, and it seems like they've got a good working relationship. Everybody seems to be very friendly. There doesn't seem to be a very hierarchical structure. It seems to be quite flat, and I think from that point of view, that's got to be good. They seem to work well together." (Advisor CONSULT. Emotions associated with interpreting: friendliness; liking.)

Randy's interpretation of the social event involved a statement about positive affect ("Everybody seems to be very friendly") that appears to be closely associated with the founder's original sensegiving action (i.e., going out for a drink with his employees). Moreover, the observed positive outcome within the employees' ranks (they have a "good working relationship," and "they seem to work well together") can also be plausibly linked to the founder's affective sensegiving action, which helped to maintain and reinforce a good working atmosphere within CONSULT.

Affective sensegiving through personal caring could be reciprocal, such as when Randy (a stakeholder) organized energizing events for Sam (the founder): "When he's got in some new clients, you know, I'm always there to take him out for a celebratory drink of lemonade or whatever it might be." This modest yet personal action conveys stakeholders' personal caring of the founder. Our data contained further evidence of this kind of feedback loop, that is, stakeholders' affective sensegiving to founders, perhaps as a result of the founders' similar efforts. Although outside the scope of this paper, exploring these links could be an interesting extension of our core model through future research.

As we explained earlier, affective sensegiving through personal caring also includes paying customized attention to individual stakeholders, for example by following up on seemingly small details that may be personally significant for stakeholders. John, an employee of CONSULT, assessed the founder's affective sensegiving actions in the following way:

"Sam is very good at following up on small points. He's very good at sending emails congratulating people about even the smallest thing. And I know he does that for everyone. He's also very good at, if he detects any slight low, he'll be on the coast taking people to lunch or whatever to make sure they're happy." (Employee CONSULT. Emotion associated with interpreting: happiness.)

John's interpretation of the founder's actions involves an explicit acknowledgment of Sam's personal caring for employees' affective needs ("to make sure that they're happy"). This 
facilitated resource mobilization, such as recruiting and retaining employees. Here's how John described why he had stayed with CONSULT after he had received a higher-pay job offer from another firm:

"I told him that I had this offer, and Sam was very, very quick to stick close to me for the next week or so, and actually in the end, even though I told [the co-founders] I wasn't going to resign, they came back with a revised pay structure for me, which was not necessary at all. They were very quick to respond to things like that, and I think that's not just me. I think they're very quick to make sure that people feel comfortable with CONSULT...that they're not going to leave." (Employee CONSULT. Emotion associated with interpreting: comfort.)

Sam's paying customized attention to the employee, his reacting quickly to the situation and staying close to John for an extended period, may well have contributed to John's decision not to leave the venture (a resource mobilization benefit for the firm). In his retrospective interpretation of Sam's actions, John assessed the revised pay as really "not necessary" but appreciated the well meaning intentions he deduced from John's quick actions. We infer that the founder's affective sensegiving triggered the stakeholder's affective interpretation, building trust (eliciting comfort), which then helped with resource mobilization for the venture. In Table 4 we present further evidence of these relationships, drawing on data from ventures in which founders performed high levels of affective sensegiving through personal caring (BUDGET, CONSULT, and DRINK).

By combining evidence from founders' affective sensegiving actions and stakeholders' affective interpretation of them, we can infer that personal caring creates stakeholders' perceptions that the founder is benevolent toward associated venture stakeholders. Indeed, founders who show that they are sensitive to the personal needs of others and make the extra effort of catering to these needs are likely to create stakeholders' perception that founders do not just entertain a purely instrumental relationship with them. Instead, stakeholders likely perceive the relationship to be imbued with caring, liking and generosity.

Affective interpreting of founders' transparent or inclusive organizing. Transparent or inclusive organizing actions involve admitting and even emphasizing the risky nature of the business, and including stakeholders in the founders' organizing for the new venture. Listening to employees and giving them the opportunity to participate in important projects are examples of inclusive organizing. Josephine, DRINK's finance director, commented on the founder's efforts in this regard:

“The qualities that Christine's got is that she actually listens, and a lot of entrepreneurs are too pigheaded to listen to anyone else's view, and had she been like that I wouldn't have been able to work with her. I've always got an opinion, and if I have an opinion I express it, even if it's not right; at least she'll listen to it. That makes you feel incredibly participative in the organization. So you don't feel a lonely voice or not being heard; you feel like you're contributing." (Finance director DRINK. Affect associated with this interpretation: feeling lonely.)

Josephine's interpretation of Christine's listening behaviors and efforts to include others in her organizing was associated with affect, in that Josephine acknowledged that Christine's actions prevented her from feeling lonely in the organization. Moreover, her appreciation of Christine's actions resulted in her motivation to contribute to the venture (i.e., she felt "incredibly participative" and was "able to work with" the founder), which represents a clear resource 
mobilization benefit for the young firm. Josephine also suggested that trust-building was the underlying mechanism between the founder's affective sensegiving and the ensuing resource mobilization: "The fact that she always listens and her energy, I guess, make me feel comfortable working for DRINK."

On the development of trust, Theresa, a senior executive with DRINK, confirmed that, "We've actually got probably about 15 people who we know and like and trust and who do a good job." And Glen, Christine's husband, also noted that, "We've got a strong team... I trust the people I am working with, they've all signed up to the same values and the same ambitions and the same dreams."

Table 4 presents more evidence of how stakeholders made sense of founders' transparent or inclusive organizing in ventures where founders performed high levels of affective sensegiving, and how this led to trust-building and facilitated resource mobilization. By combining evidence from both founders' affective sensegiving actions and stakeholders' affective interpretation of them, we can infer that transparent or inclusive organizing creates stakeholders' perceptions that the founder, and by association the young organization, possess integrity. Indeed, founders who demonstrate transparency make it easy for others to observe them. This likely creates stakeholders' perceptions that the founders are honest and have little to hide. And founders who show inclusiveness make it easy for others to interact with them. This allows stakeholders to monitor the consistency between founders' words and actions over time and thus shapes their perceptions of founders' integrity.

\section{Emotional Assuring}

Based on our findings on the links between founders' affective sensegiving, stakeholders' affective interpreting and trust-building, we call the three types of affective sensegiving actions shown in Table 2 (displaying socially valued entrepreneurial characteristics, personal caring, and transparent or inclusive organizing) "emotional assuring." Emotional assuring suggests the trust-building effect of affective sensegiving in the specific context of firm creation. This is encapsulated vividly in Thad's explanation of his decision to support DRINK at a very early stage, after learning about the fledgling organization while browsing through a trade journal: "The team had passion and drive. They seemed to love their products, they seemed to enjoy selling and they seemed to enjoy the thrill of marketing something... I felt totally reassured." Thad invested $£ 50,000$ of his own funds, and joined DRINK as a board member.

Our emerging theory on emotional assuring is summarized in Figure 1. The core elements of Figure 1 (i.e., those within the dotted box) summarize the empirically grounded concepts, and the relationships between them, that we have described so far. The main proposition following from our inductive theory is that, all things being equal, founders' emotional assuring is positively associated with resource mobilization from stakeholders. This positive effect is facilitated and corroborated by organization stakeholders' affective interpretations of founders' verbal statements and actions. 


\section{Figure 1}

Founders' Emotional Assuring and Organization Building

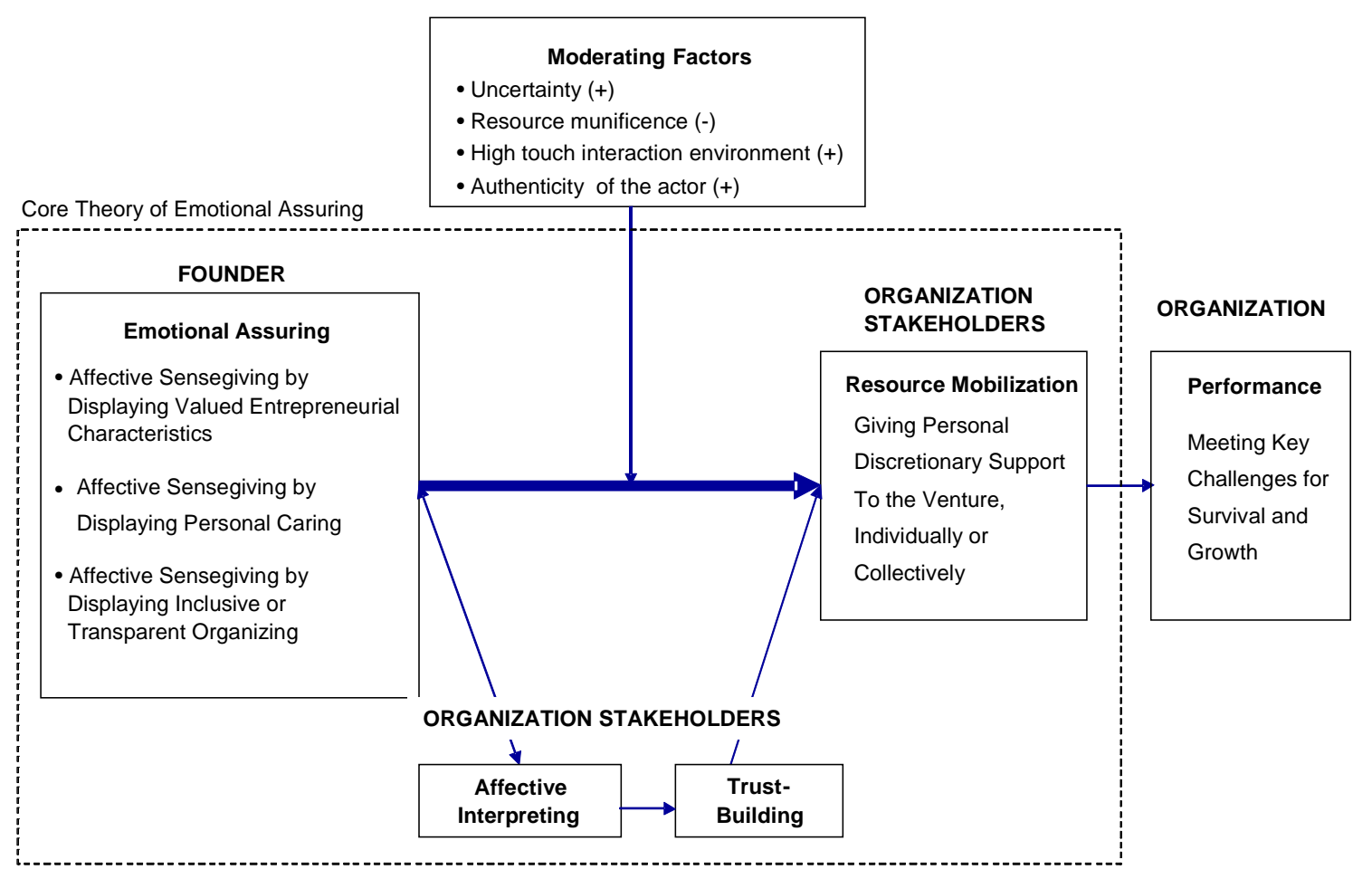

Nuancing our core theory, our data suggest two more moderating conditions besides the ones mentioned earlier (uncertainty and resource munificence). These two new moderating conditions involve the nature of founders' interactions with stakeholders. We call the first of the two "high-touch" interaction, meaning proximal, face-to-face interactions between founders and stakeholders. This moderating condition is distinct from what we denote as founders showing personal caring, because high-touch interaction between founders and stakeholders could be conducted in a purely cognitive, or even impersonal manner. And affective personal caring does not exclusively happen through face-to-face interaction. We posit, however, that the more impersonal the interaction between the founder and the stakeholders, the weaker the positive association between emotional assuring and resource mobilization (Appendix B explains this moderating condition in more detail).

We call the second moderating condition related to the nature of founder-stakeholder interactions authenticity, meaning how true and honest founders are to themselves in social interactions. Authenticity involves the true and complete self, which includes one's affect (Hochschild, 1983), and represents a more demanding criterion than integrity - consistency between words and actions (Whitener et al., 1998). This moderating condition is distinct from founders' displaying inclusive or transparent organizing, because even individuals who are not always honest with themselves in all social interactions could attempt to include others in, and be transparent about, their organizing efforts. We theorize that the lower the authenticity of the founder, the weaker the positive association between emotional assuring and resource mobilization (see Appendix B for more details). 
A further extension of our core model is the hypothesized positive association between resource mobilization and organization performance, such as meeting key challenges for survival and growth. This is presented in Appendix C, which describes how stakeholders spontaneously dealt with unexpected challenges to their firms.

Limitations to emotional assuring. Besides the two moderating conditions, it seems difficult for founders to use emotional assuring equally well on every stakeholder - even where founders use it often and many stakeholders agree about its benefits. At CONSULT, for example, we detected a dissenting voice among the six people we interviewed; one employee indicated that he no longer wanted to stay with the growing company and therefore did not feel inclined to do any more work than was required of him. He believed that the company had inadequately recognized his earlier contributions:

"Recently I've been off-project or on the bench for about three or four months and I was basically advised that if a project wasn't found, then I'd be made redundant, which I felt was quite unfair considering that I'd actually spent about four out of the five years fulltime working and keeping the company afloat.” (Employee CONSULT.)

Thus, even in firms that practiced emotional assuring, founders sometimes failed to tailor it to specific individuals - and even if they do, some stakeholders may not appreciate their efforts. Because effective emotional assuring often requires challenging personalized customization for stakeholders with diverse needs and preferences, not all attempts succeed.

Moreover, some founders may not use much emotional assuring at all. Michael, the founder of INVEST, for example, appraised a disruptive event in a cognitive, affect-neutral way when he described why and how the top team fired one of their original partners:

"We learned that he was not working together with us, which was a bit stressful, because I mean, I've been sitting with this person for the last four years. But he was just too political, and he was really bad-mouthing everyone else so he could get ahead of the others. We felt that that was unjustified and asked him to leave, which wasn't traumatic, but it was a little bit tense." (Founder INVEST.)

Michael did not mention any affective sensegiving action he had tried with the ousted partner or with people who interacted with this partner, even though this might have been beneficial (in contrast, Christine, the founder of DRINK, made sure that any parting employees felt good toward her venture because "if they leave and they feel wonderful about the company, they're going to tell everybody else about it”). At first glance, this lack of emotional assuring seems surprising given that these actions are relatively easy and economically inexpensive for founders to use, and the associated resource mobilization benefits can be significant. Landis, the founder of INCUBATE, gave us a hint about why he may have been less engaged in it: "We had always said to ourselves that we would let rationality get the better of emotion, and if we saw something was not going to work, we wouldn't do it." Landis seemed to have espoused the generalized view that emotions are dysfunctional in the management of a business.

A second factor that may have prevented some founders from using emotional assuring could have been a lack of appreciation of how important these actions really are. Alex, a former partner at INVEST, who subsequently retrained as an executive coach, explained that he had preferred to handle the significant problems that occurred within the management team of their young organization in a more cognitive, task-focused manner: "What we did was to sit down [with a colleague who had a problem] and talk to him, talk him through the logical steps so he 
could see whether he could or couldn't do what he wanted to achieve." Alex regretted this purely cognitive task-oriented influencing approach later:

"My subsequent training is as an executive coach. Had I had this skill set back in 19992000, I'm sure things would have developed differently. I would have been able to make interventions with people such that they would have stayed together as a team. But I didn't know and obviously you can't rewrite history... Management of emotions, getting people to understand what's happening to others is a key part of the coaching I now provide. If only I knew then what I know now, I think we could have helped the individuals in INVEST." (Co-founder INVEST.)

In other words, Alex regretted not having included affect (here, "management of emotions") as part of his influencing and sensegiving ("getting people to understand what's happening") when it could have made a difference in the early, defining days of the venture.

\section{Discussion and Conclusion}

We have introduced affective sensegiving as a novel general concept and emotional assuring that is more specific to the context of building new firms. Our study reveals that there are wide variances in founders' engaging in affective sensegiving. Beyond integrating affect with cognition in sensegiving actions, we have also shown that these actions are associated with important firm-level consequences such as resource mobilization. Our study thus extends the nature of sensegiving because most of the works on sensegiving to date have been mainly cognition-focused and descriptive, and the organizational outcomes of sensegiving have been under-researched.

Moreover, based on stakeholders' interpretation of founders' actions, we infer how and why founders' various types of affective sensegiving actions, to which we refer as "emotional assuring," help build three dimensions of trustworthiness: competence, benevolence, and integrity. Below, we elaborate theoretically how these actions help build trust in complementary ways: fostering the three dimensions of trustworthiness as well as cognition- and affect-based trust (Chua et al., 2008; McAllister, 1995).

Competence. By combining evidence from both founders' affective sensegiving actions and stakeholders' affective interpretation of these actions with regard to displaying socially valued entrepreneurial characteristics, we infer that this type of affective sensegiving likely creates stakeholders' perceptions that the founder is competent to build a successful business. In the early days of firm creation, success hinges on founders' ability. In making entrepreneurship characteristics salient to stakeholders who might value them, founders generate positive emotional and cognitive responses, experienced by them and their stakeholders when their goals and identities are validated or enhanced (Carver and Scheier, 1998; Cardon et al., 2009). As founders display passion or calm confidence about their firm's offerings, for example, stakeholders interpret these affective displays as manifestations of commitment and conviction in the value of their new businesses. This type of affective sensegiving thus helps build cognition-based trust, a type of trust that relies on judgment of another party's competence in task delivery (Chua et al., 2008; McAllister, 1995).

Benevolence. Our finding linking founders' affective sensegiving actions displaying personal caring to trust-building seems consistent with Whitener and colleagues' (1998) hypothesis that 
managers' actions demonstrating consideration and sensitivity for other employees' needs and interests, and refraining from exploiting others for the benefits of the managers' own interests, is part of trustworthy behavior. Stakeholders likely experience this type of affective sensegiving as an "emotional gift" of care and liking (Clark, 2004). In turn, employees are likely to perceive their managers as loyal and benevolent. Such perceived managerial loyalty leads to trust between mentors and protégés (Butler, 1991; Jennings, 1971).

By combining evidence of founders' affective sensegiving actions and stakeholders' affective interpretation of them, we infer that displaying personal caring for stakeholders likely builds stakeholders' affect-based trust, which relies on emotional bonds that arise from people's genuine care and concern for others' welfare (Chua et al., 2008; McAllister, 1995). This type of trust is more enduring and generalizable over situations than cognition-based trust (Lewicki and Bunker, 1996). People are reluctant to work with task-competent people whom they do not personally like because they may perceive them to be ill-intentioned and unwilling to cooperate in good faith (Casciaro and Lobo, 2008). Once formed, beliefs that a young firm and/or the founders will protect stakeholders' wellbeing can spill over to other domains and reduce fear of future harm (Williams, 2007). Through these founders' actions, stakeholders might even attribute a benevolent "personal character" to the young organization and anthropomorphize it (Kraatz and Block, 2008).

Integrity. Our finding linking founders' affective sensegiving actions with regard to transparent or inclusive organizing to trust-building seems consistent with Whitener and colleagues' (1998) hypothesis that managers' behavioral reliability and integrity (consistency between words and actions), open and honest exchange, and sharing and delegation of control promote employees' trust. Employees perceive they have a greater control over decisions that affect them and that there is less risk of opportunism on the part of the manager. Inclusive organizing with delegation of control also has symbolic value, in that managers demonstrate significant trust for their employees (Rosen and Jerdee, 1977).

By combining evidence of founders' affective sensegiving actions and stakeholders' affective interpretation of them, we infer that displaying transparent or inclusive organizing helps create stakeholders' perceptions that the founder (and, by extrapolation, the young firm) is disposed to behave with high integrity and needs a minimum of close monitoring. Displays of managerial inclusivity and transparency make stakeholders feel less vulnerable to the threats of information asymmetry and opportunism that often exist in young ventures (Amit, Brander, and Zott, 1998). This type of influencing likely builds stakeholders' cognition-based trust, because this type of trust partly relies on judgment of another party's reliability in task operations (Chua et al., 2008; Kotha and Wicks, 2008; McAllister, 1995).

The moderating conditions of uncertainty, resource munificence, high-touch interaction and personal authenticity that we identified also fit well with these trust-based theoretical explanations. First, uncertainty heightens the threat of opportunism (Williamson, 1975) and therefore amplifies the benefits of trust-based interactions between founders and stakeholders. Second, resource mobilization in more munificent environments becomes easier, and this may lessen the relative importance of trust for founders. Third, high-touch interaction can be costly to founders in terms of the time and effort it requires, something stakeholders generally recognize and appreciate, further increasing their perception of founders' trustworthiness (Williams, 2007). Moreover, founders' actions may have greater impact when experienced closely and personally. Lastly, perceived authenticity is essential to assumed trustworthiness. Authenticity - being sincere, transparent, connected to self and to others - is widely valued in 
modern Western societies (Weber, Heinze, and DeSoucey, 2008). Opportunistic individuals should find trust-building emotional assuring difficult to fake for two reasons: 1) the facial expressions of certain emotions, such as concern, are more difficult to control voluntarily than others, such as joy (Ekman, 1985), and 2) frequently, true feelings leak out through behavioral channels that are less controllable (Ambady and Rosenthal, 1992). People can choose their words carefully but are less adept at controlling an internally consistent set of facial, vocal and bodily expressions. In the long run, through repeated affective sensegiving actions, founders provide many opportunities for stakeholders to observe and detect inconsistencies between verbal and nonverbal behavior, between benevolent and harmful actions.

As various types of emotional assuring actions help build different forms of trust, whether cognition- or affect-based, our study adds nuance to an existing tension in the trust literature. Scholars have found that cognition- and affect-based trust can undermine each other in large, established companies. For instance, when A receives economic resources or task advice from B, the level of cognition-based trust that A has for B is higher than it might otherwise be, but the level of affect-based trust is lower. Instrumental exchange undermines affect because they are posited to be "naturally" incompatible with each other (Chua et al., 2008). Our study suggests that this tension could be less pronounced in the context of young firms. Risks inherent in firm creation are so high that both cognition- and affect-based trust are needed to allay stakeholders' nervousness, and one form of trust complements the other.

Emotional assuring as an affect-including action to build trust may help explain some of the inconsistent results in prior empirical studies. Lack of trust can help explain, for example, why Chen and colleagues (2009) found that display of entrepreneurial passion failed to persuade venture capitalists in one-off interactions (business plan presentations). The authors suspected that more substantive enabling mechanisms might be required. Trust generated through repeated emotional displays, for example, could be such a mechanism. For entrepreneurs, trust may be as important to cultivate as legitimacy, which is generally viewed as a cornerstone of resource accumulation and growth (Zimmerman and Zeitz, 2002).

Summary of contributions. To the best of our knowledge, no prior empirical research has systematically examined the variety of affective sensegiving actions that founders use and how these actions influence firm outcomes-resource mobilization. Our research may also be the first study to show how and when resource holders are susceptible to affective sensegivinginterpretation of trustworthiness.

Our study thus contributes to the literatures on sensegiving and trust, but also to the emerging stream of research into entrepreneurial agency and firm-building as a process of social construction (e.g., Hargadon and Douglas, 2001; McMullen and Shepherd, 2006; Rindova, Barry, and Ketchen, 2009; Schoonhoven and Romanelli, 2001; Zott and Huy, 2007) and developing relational capital (e.g., Adler and Kwon, 2002; Blatt, 2009; Graebner, 2009). Our findings underline how resource-poor founders can still "create something from nothing" through using emotional assuring actions that elicit support, individually and collectively, from existing and prospective firm stakeholders. This complements recent findings on entrepreneurial bricolage, a process in which founders combine given physical, social or institutional inputs (Baker and Nelson, 2005). Consistent with the literature on resourcing in practice (Feldman, 2004; Feldman and Quick, 2009), our analysis shows that stakeholders' resources can also be created or renewed, not just recombined, thus substituting traditional inputs such as financial capital and yielding important benefits for the young firms. Founders can perform emotional assuring to mobilize resources, which can help create further tangible resources such as 
revenues and products, and intangible ones such as loyalty, enthusiasm and reciprocal affective sensegiving. As described in Appendix C, this can help founders deal with unexpected challenges to their firms, even under conditions of low environmental munificence.

Future research. Our study suggests rich opportunities for future research. Inductive findings based on a limited number of cases need to be further validated by testing large samples. Because the context of this study is restricted to one geographical area (London, United Kingdom), the specificity of this cultural milieu could have influenced the specific variety of affective sensegiving that we found, and its effectiveness could vary in a different culture. Despite this geographical limitation, we suspect that our categories of emotional assuring actions are likely to apply to many diverse contexts insofar as they are related to building different dimensions of trust. What may vary, however, are the specific affective sensegiving actions that founders are likely to use to develop these. Future research can enrich our understanding of the role of emotional assuring in organization creation in diverse cultural contexts.

Future research can also validate the usefulness of affective sensegiving in other uncertain contexts such as strategic change or post-merger integration. In addition, scholars can also investigate why founders or other corporate managers differ in their practice of affective sensegiving. Reasons may range from variations in emotional intelligence and personality traits to socialization within the Protestant work ethic, which generally considers paying attention to affect at work as unprofessional (Sanchez-Burks, 2002). Alternatively, various founders can have different models of employment relations that emphasize tangible factors such as task and money more than intangible ones such as values and affect (Baron, Burton, and Hannan, 1996). Although our data do not allow us to make definitive causal statements, we posit that some combination of nature (e.g., emotional intelligence or personality attributes) and nurture (e.g., mental models about the weakness of paying attention to emotions at work) may be at play.

In addition, researchers could explore, theoretically as well as empirically, interactions among affective sensegiving and other types of social influence, such as symbolic management, which is relevant to firm creation (e.g., Rao, 1994; Zott and Huy 2007). Symbolic management can be construed as a process of story-telling (Lounsbury and Glynn 2001), and what makes stories convincing could well be their emotional appeal (Weick, 1999). Rafaeli and Vilnai-Yavetz (2004) have shown how making sense of the symbolic dimensions of mundane artifacts (e.g., the color of a bus) can evoke strong emotions toward both the artifact and the organization that produces it. Affective sensegiving may, therefore, complement symbolic management, and entrepreneurs could draw on both in their efforts to mobilize resources.

To conclude, our study considers people as whole beings-operating on both cognitive and affective levels - in business settings. Founders of new firms who appeal to stakeholders' hearts as well as their minds should be more likely to tip the balance in their favor, especially when times are tough, than founders who ignore emotions in their sensegiving to stakeholders. We hope that our research paves the way toward a more complete understanding of the social processes by which entrepreneurs form and develop organizations, which will help us appreciate the enormous accomplishments through which they create new wealth for themselves, their stakeholders and the societies in which they are embedded. 


\section{References}

Adler, P.S. and S.W. Kwon (2002), "Social capital: Prospects for a new concept." Acad. Management Rev. 27, pp. 17-40.

Aldrich, H.E. and C.M. Fiol (19949, "Fools rush in? The institutional context of industry creation,"Acad. Management Rev. 19, pp. 645-670.

Aldrich, H.E. and M. Ruef (2006), "Organizations evolving," 2nd ed. Sage Publications, Thousand Oaks, CA.

Ambady, N. and R. Rosenthal (1992), "Thin slices of expressive behavior as predictors of interpersonal consequences: A meta-analysis," Psych. Bull. 111, pp. 256-274.

Amit, R., J. Brander and C. Zott (1998), "Why do venture capital exist? Theory and Canadian evidence," J. Bus. Vent. 13, pp. 441-467.

Baker, T. and R.E. Nelson (2005), "Creating something from nothing: Resource construction through entrepreneurial bricolage," Admin. Sci. Quart. 50, pp. 329-366.

Barger, P.B. and A.A. Grandey (2006), "Service with a smile and encounter satisfaction: emotional contagion and appraisal mechanisms," Acad. Management J. 49, pp. 1229-1238.

Baron, R.A. (2007), "Behavioral and cognitive factors in entrepreneurship: Entrepreneurs as the active element in new venture creation," Strategic Entre, 1, pp. 167-182.

Baron, R.A. (2008), "The role of affect in the entrepreneurial process," Acad. Management Rev. 33, p.p 328-340.

Baron, R.A. and G. Markman (2000), "Beyond social capital: how skills can enhance entrepreneurs' success,” Acad. Management. Exec. 14, pp. 106-116.

Baron, R.A. and G. Markman (2003), "Beyond social capital: the role of entrepreneurs' social competence in their financial success," J. Bus. Vent, 18, pp. 41-61.

Baron, J.N., D. Burton and M. Hannan (1996), "The Road Taken: Origins and Evolution of Employment Systems in Emerging Companies," Industrial \& Corporate Change 5, pp. 239-275.

Baron, R.A. and J. Tang (2009), "Entrepreneurs' social skill and new venture performance: Mediating mechanisms and cultural generality," J. of Management, 35, pp. 282-306.

Barsade, S.G. (2002), "The ripple effect: emotional contagion and its influence on group behaviour," Admin. Sci. Quart, 47, pp. 644-675.

Baum, J.R., E.A. Locke and K G. Smith (2001), "A multidimensional model of venture growth," Acad. Management J, 44, pp. 292-303.

Baum, J.R. and E.A. Locke (20049, "The relationship of entrepreneurial traits, skill and motivation to subsequent venture growth," J. App. Psych, 89, pp. 587-598.

Blatt, R. (2009), "Tough love: How communal schemas and contracting practices build relational capital in entrepreneurial firms," Acad. Management, Rev. 34, pp. 533-551.

Bolino, M.C. (1999), "Citizenship and impression management: Good soldiers or good actors?,” Acad. Management Rev. 24, pp. 82-98. 
Brown, S.L. and K.M. Eisenhardt (1997) "The art of continuous change: Linking complexity theory and time-paced evolution in relentlessly shifting organizations," Admin. Sci. Quart. 42, pp. 1-34.

Burt, R S. and M. Knez (1996), "Trust and third-party gossip,” in R.M. Kramer and T. R. Tyler (eds.), "Trust in organizations: Frontiers of theory and research," Sage Publications, Thousand Oaks, CA, pp. 68-89.

Busenitz, L.W. and J. B. Barney (1997), "Differences between entrepreneurs and managers in large organizations: biases and heuristics in strategy decision-making," J. of Bus. Vent., 12, pp. 9-31.

Butler, J.K. (1991), "Toward understanding and measuring conditions of trust: Evolutions of conditions of trust inventory," J. of Management 17, pp. 643-663.

Cardon, M.S. (2008), "Is passion contagious? The transference of entrepreneurial passion to employees," Human Resource Management Review, 18, pp. 77-86.

Cardon, M.S., J. Wincent, J. Singh and M. Drnovsek (2005), "Entrepreneurial passion: The nature of emotions in entrepreneurship," Academy of Management Proceedings, G1.

Cardon, M., J. Wincent, J. Singh and M. Drnovsek (2009), "The nature and experience of entrepreneurial passion,” Acad. Management Rev., 34, pp. 511-532.

Carver, C.S. and M.F. Scheier (1998), "On the self regulation of behaviour," Cambridge University Press, Cambridge.

Casciaro, T. and M. S. Lobo (2008), "When task competence is irrelevant: the role of interpersonal affect in instrumental ties," Acad. of Management, Proc., pp. 1-6.

Chen, X.-P., X. Yao and S. Kotha (2009), "Entrepreneur passion and preparedness in business plan presentations: A persuasion analysis of venture capitalists' funding decisions," Acad. Management Journal,. 52, pp. 199-214.

Child, J., G. Möllering (2003), "Contextual confidence and active trust development in the Chinese business environment,” Organ. Sci,. 14, pp. 69-80.

Chua, R.Y.J., P. Ingram and M.W. Morris (2008), "From the head and the heart: Locating cognition- and affect-based trust in managers' professional networks," Acad. Management Journal, 51, pp. 436-452.

Cialdini, R.B. (2001), "Harnessing the science of persuasion," Harvard Business Review, 79, pp. 72-79.

Clark, C. (2004), "Emotional gifts and 'your first' micro politics: Niceness in the socialemotional economy," A.S.R. Manstead, N. Frijda and A. Fischer, eds. "Feelings and emotions: the Amsterdam Symposium," Cambridge University Press, Cambridge, pp. 402-421.

Corley, K G. and D.A. Gioia (2004), "Identity ambiguity and change in the wake of a corporate spin-off,” Admin. Sci. Quart, 49, pp. 173-208.

Damasio, A. (1994), “Descartes' error: emotion, reason and the human brain,” G.P. Putnam's Sons, New York. 
Damasio, A. R. (2003), “Fundamental feelings,” Nature, pp. 413-781.

Dirks, K.T. and D.L. Ferrin (2001), "The role of trust in organizational settings," Organ. Sci., 12, pp. 450-467.

Dorado, S. (2005), "Institutional entrepreneurship, partaking, and convening," Organ. Stud., 26, pp. 385-414.

Dunn, J.R. and M.E. Schweitzer (2005), "Feeling and believing: The influence of emotion on trust," J. Personnality Soc. Psych., 88, pp. 736-748.

Dutton, J.E., P.R.J. Frost, M.C. Worline, J.M. Lilius and J.M. Kanov (2002), “Leading in times of trauma. Harvard Business Review, 80, pp. 54-61.

Dutton, J.E., E. Heaphy (2003), “The power of high-quality connections," in K.S. Cameron, J.E. Dutton and R.E. Quinn (eds.), "Positive organizational scholarship: Foundations of a new discipline,” San Francisco: Berrett-Koehler Publishers, 17, pp. 263-268.

Edmondson, A. 1999. Psychological safety and learning behavior in work teams, Admin. Sci. Quart. 44 350-383.

Edmondson, A. (2004), "Psychological safety, trust and learning in organizations: A group-level lens," in R. Kramer, and K. Cook, (eds.), "Trust and distrust in organizations: Dilemmas and approaches," Russell Sage Foundation, pp. 239-272.

Eisenhardt, K.M. (1989), "Building theories from case study research," Acad. Management Rev., 14, pp. 532-550.

Eisenhardt, K.M. and M.E. Graebner (2007), "Theory building from cases: Opportunities and challenges," Academic Management Journal, 50, pp. 25-32.

Ekman, P. (1985), “Telling lies,” Norton, New York.

Elfenbein, H. A. (2007), "Emotion in organizations: A review and theoretical integration," Academy of Management Annals, 1, pp. 315-386.

Elsbach, K.D., R.M. Kramer (2003), “Assessing creativity in Hollywood pitch meetings: Evidence for a dual-process model of creativity judgments," Academic Management Journal, 46, pp. 283-301.

Feldman, M.S. (2004), "Resources in emerging structures and processes of change," Organ. Sci., 15, pp. 295-309.

Feldman Barrett, L. and J.A. Russell (1998), "Independence and bipolarity in the structure of current affect,” J. Personality Soc. Psych., 74, pp 967-984.

Feldman, M.S. and K.S. Quick (2009), “Generating resources and energizing frameworks through inclusive public management," International Public Management Journal, 12, pp. 137-171.

Fiss, P.C., E.J. Zajac (2006), “The symbolic management of strategic change: Sensegiving via framing and decoupling, Academic Management Journal, 49, pp. 1173-1193.

Forgas, J.P. (2000), “Affect and information processing strategies: An interactive relationship," J.P. Forgas (ed.), "Feeling and thinking: The role of affect in social cognition," Cambridge, U.K., Cambridge University Press. 
Forgas, J. and J.M. George (2001), "Affective influence on judgments and behavior in organizations: an information processing perspective," Org. Behav. and Hum. Dec. Proc. 86, pp. 3-34.

Fredrickson, B. 1998. Cultivated emotions: parental socialization of positive emotions and selfconscious emotions. Psych. Inq. 9 279-281.

Gabarro, J.J. (1978), "The development of trust, influence and expectations," in A. G. Athos, J.J. Gabarro (eds.), "Interpersonal behaviors: communication and understanding in relationships," Prentice-Hall, Englewood Cliffs, NJ, pp. 290-303.

Gardner, W.L. and B.J. Avolio (1998), "The charismatic relationship: A dramaturgical perspective," Academic Management Review, 23, pp. 32-58.

Gartner, W.B. (1985), “A conceptual framework for describing the phenomenon of new venture creation," Academic Management Review, 10, pp. 696-706.

Gioia, D.A. and K. Chittipeddi (1991), "Sensemaking and sensegiving in strategic change initiation,” Strategic Management Journal, 12, pp. 433-448.

Gioia, D.A., J. B. Thomas (1996), "Identity, image, and issue interpretation: Sensemaking during strategic change in academia," Admin. Sci. Quart., 41, pp. 370-403.

Graebner, M. (2009), "Caveat vendor: Trust asymmetries in acquisitions of entrepreneurial firms," Academic Management Journal. 52, pp. 435-472.

Grandey, A.A. and A. Brauburger (2002), "The emotion regulation behind the customer service smile," in R. Lord, R. Klimoski, R. Kanfe (eds.), "Emotions in the workplace: Understanding the structure and role of emotions in organizational behaviour," Jossey-Bass, San Francisco, CA, pp. 260-294.

Hargadon, A.B. and Y. Douglas (2001), "When innovations meet institutions: Edison and the design of the electric light," Admin. Sci. Quart., 46, pp. 476-501.

Hochschild, A.R. (1983), "The managed heart: Commercialization of human feeling," University of California Press, Berkeley, CA.

Huy, Q. (2002), "Emotional balancing of organizational continuity and radical change: The contribution of middle managers," Admin. Sci. Quart., 47, pp. 31-69.

Isen, A.M., K. Daubman and G.P. Nowicki (1987), "Positive affect facilitates creative problem solving," J. Personnality Soc. Psych., 52, pp. 1122-1131.

Jennings, E.E. (1971), “Routes to the executive suite,” New York: McGraw-Hill.

Johnson, E.J and A. Tversky (1983), "Affect, generalization, and the perception of risk," J. Personnality Soc. Psych., 45, pp. 20-31.

Kahn, W.A. (1990), "Psychological conditions of personal engagement and disengagement at work," Academic Management Journal, 33, pp. 692-724.

Kaplan, S.N. and P. Strömberg (2004), "Characteristics, contracts, and actions: Evidence from venture capitalist analyses,” Journal Finance, 59, pp. 2177-2210. 
Kotha, S., A. Wicks (2008), "The creation and evolution of trust: The case of eBay and its rivals in online auctions," Working paper.

Kraatz, M.S. and E.S. Block (2008), "Organizational implications of institutional pluralism," in R. Greenwood, C. Oliver, K. Kerstin Sahlin-Andersson and R. Suddaby (eds.), "The handbook of organizational institutionalism," Sage Publications, London.

Larsen, R.J. and E.E. Diener (1992), "Promises and problems with the cirumplex model of emotion," M. S. Clark (ed.), "Review of personality and social psychology: Emotion and social behaviour," Newbury Park, CA: Sage, PP. 25-59.

Lawler, E.J. (2001), “An affect theory of social exchange," American Journal of Sociology, 107, pp. 321-352.

Lawler, E.J., J. Yoon and J. (1996), "Commitment in exchange relations: Test of a theory of relational relational cohesion,” American Sociological Review, 61, pp. 89-108.

Lazarus, R.S. (1991), “Emotion and adaptation,” New York: Oxford University Press.

Lerner, J.S. and D. Keltner (2001), "Fear, anger, and risk," J. Personnality Soc. Psych., 81, pp. 146-159.

Lewicki, R.J. and B.B. Bunker (1996), "Developing and maintaining trust in work relationship," in R.M. Kramer and T.R. Tyler (eds.), "Trust in organizations: Frontiers of theory and research," Sage Publications, Thousand Oaks, CA, pp. 114-139.

Lounsbury, M. and M.A. Glynn (2001), "Cultural entrepreneurship: Stories, legitimacy, and the acquisition of resources," Strat. .Management Journal, 22, pp. 545-564.

MacMillan, I.C., L. Zemann and P.N. SubbaNarashima (1987), "Criteria distinguishing successful from unsuccessful ventures in the venture screening process," J. Bus Vent., 2, pp. 123-137.

Maitlis, S. and T.B. Lawrence (2007), "Triggers and enablers of sensegiving in organizations," Academic Management Journal, 50, pp. 57-84.

Martin, J., K. Knopoff and C. Beckman (1998), "An alternative to bureaucratic impersonality and emotional labor: Bounded emotionality at the Body Shop,” Admin. Sci. Quart., 43, pp. 429-469.

Mayer, R.C., J. H. Davis and F. D. Schoorman (1995), “An integrative model of organizational trust,” Academic Management Review, 20, pp. 709-734.

McAllister, D.J. (1995), "Affect and cognition-based trust as foundations for interpersonal cooperation in organizations," Academic Management Journal, 38, pp. 24-59.

McMullen, J.S. and D.A. Shepherd (2006), "Entrepreneurial action and the role of uncertainty in the theory of the entrepreneur," Academic Management Review, 31, pp. 132-152.

Michl, T., I.M. Welpe, M. Spöorrle, M and a. Picot (2009), "The role of emotions and cognitions in entrepreneurial decision-making," in A.O. Casrud, M. Brännback (eds.), "Understanding the entrepreneurial mind - International studies in entrepreneurship,” pp. 167-180.

Pelzer, P. (2005), “Contempt and organization: Present in practice ignored by research?," Organization Studies, 26, pp. 1217-1227. 
Powell, W.W. and L. Smith-Doerr (1994), "Networks and economic life," in N.J. Smelser, R. Swedberg (eds.), "The Handbook of economic sociology," Princeton University Press, Princeton, NJ, pp. 368-402.

Puranam P. and B.S. Vanneste (2009), "Trust and Governance: Untangling a Tangled Web," Academic of Management Review, 34, pp. 11-31.

Putnam, L.L. and D.K. Mumby (1993), "Organizations, emotion and the myth of rationality," S. Fineman (ed.), "Emotion in organizations," Sage Publications, London, pp. 36-57.

Rafaeli, A. and R.I. Sutton (1991), "Emotional contrast strategies as means of social influence: Lessons from criminal interrogators and bill collectors," Academic Management Journal, 34, pp. 749-775.

Rafaeli, A. and I. Vilnai-Yavetz (2004), "Emotion as connection of physical artifacts and organizations," Organ. Sci., 15, pp. 671-686.

Rao, H. (1994), "The social construction of reputation: Certification contests, legitimation and the survival of organizations in the American automobile industry: 1895-1912," Strategic Management Journal, 13, pp. 29-44.

Rindova, V., D. Barry and D.J. Ketchen (2009), "Entrepreneuring as emancipation," Academic Management Review, 34, pp. 477-491.

Ring, P.S. and A.H. Van de Ven (1994), "Developmental processes of cooperative interorganizational relationships," Academic Management Review, 19, pp. 90-118.

Robinson, M.D. and G.L. Clore (2002), "Episodic and semantic knowledge in emotional selfreport: evidence for two judgment processes,” J. Personnality Soc. Psych., 83, pp. 198-215.

Rosen, B. and T.H. Jerdee (1977), "Influence of subordinate characteristics on trust and use of participative decision strategies in a management simulation,” J. Applied Psych. 62, pp. 628-631.

Russell, J.A. and G. Pratt (1980), "A Description of the Affective Quality Attributed to Environments," J. Personnality Soc. Psych., 38, pp. 311-322.

Sanchez-Burks, J. (2002), "Protestant relational ideology and (in)attention to relational cues in work settings," J. Pers. and Soc. Psych., 83, pp. 919-929.

Schoonhoven, C.B. and E. Romanelli (2001), "The entrepreneurship dynamic," Stanford, CA: Stanford University Press.

Schwarz, N. and G.L. Clore (1988), "How do I feel about it? The informative function of affective states," in K. Fiedler and J. Forgas (eds.), "Affect, cognition and social behaviour," pp. 44-62.

Schwarz, N. (1990), "Feelings as information: Informational and motivational functions of affective states," in E. Higgins and R. Sorrentin, (eds.), "Handbook of motivation and cognition: Foundations of social behaviour.” New York, Guilford Press, 2, pp. 527-561.

Schwarz, N. and G.L. Clore (2006), "Feelings and phenomenal experiences," E.T. Higgings, A. Kruglanski (eds.), "Social psychology: A handbook of basic principles," 2nd ed., Guilford Press, New York. 
Seo, M.-G. and L.F. Barrett (2007), "Being emotional during decision making -- good or bad? An empirical investigation,” Academic Management Journal, 50, pp. 923-940.

Shepherd, D.A. (1999), "Venture capitalists' assessment of new venture survival," Management Sci. 45, pp. 621-632.

Sirmon, D.G., M. Hitt and R.D. Ireland (2007), "Managing firm resources in dynamic environments to create value: Looking inside the black box," Academic Management Review, 32, pp. 273-292.

Smith, C.A. and P. C. Ellsworth (1985), "Patterns of cognitive appraisal in emotion," J. Pers. and Soc. Psych., 48, pp. 813-838.

Staw, B.M. amd S.G. Barsade (1993), "Affect and managerial performance: A test of the sadderbut-wiser vs. happier-and-smarter hypotheses,” Admin. Sci. Quart., 38, pp.304-331.

Strauss, A.L. and J.M. Corbin (1998), "Basics of qualitative research: Techniques and procedures for developing grounded theory,” (2nd ed.), Thousand Oaks: Sage Publications.

Sy, T., S. Côté and R. Saavedra (2005), "The contagious leader: Impact of the leader's mood on the mood of group members, group affective tone, and group processes," J. Applied Psych., 90, pp. 295-305.

Thornhill, S. and R. Amit (2003), "Learning about failure: Bankruptcy, firm age, and the resource-based view," Organ. Sci., 14, pp. 497-509.

Tiedens, L.Z. and S. Linton (2001), "Judgement under emotional certainty and uncertainty: the effects of specific emotions on information processing," J. Pers. and Soc. Psych., 81, pp. 973-988.

Uzzi, B. (1997), "Social structure and competition in interfirm networks: the paradox of embeddedness,” Admin. Sci. Quart., 42, pp. 35-67.

Van Maanen, J. (1979), "The fact of fiction in organizational ethnography," Admin. Sci. Quart., 24, pp. 539-550.

Weber, K., K.L. Heinze and M. DeSoucey (2008), "Forage for thought: Mobilizing codes in the movement for grass-fed meat and dairy products," Admin. Sci. Quart., 53, pp. 529-567.

Weick, K. E. (1999), “That's moving: Theories that matter,” J. Management Inquiry, 8, pp. 134-142.

Westphal, J.D. and E.J. Zajac (1998), "The symbolic management of stockholders: Corporate governance reforms and shareholder reactions," Admin. Sci. Quart., 43, pp. 127-153.

Whitener, E.M., S.E. Brodt, M.A. Korsgaard and J.M. Werner (1998), "Managers as initiators of trust: An exchange relationship framework for understanding managerial trustworthy behaviour," Academic Management Review, 23, pp. 513-530.

Williams, M. 2001. In whom we trust: Social group membership as an affective context for trust development. Acad. Management Rev. 26 377-396.

Williams, M. (2007), "Building genuine trust through interpersonal emotion management: A threat regulation model of trust and collaboration across boundaries," Academic Management Review, 32, pp. 5957-5621. 
Williamson, O.E. (1975), "Markets and Hierarchies. Analysis and Antitrust Implications," The Free Press, New York.

Yin, R.K. (1994), “Case study research: Design and methods,” (2nd ed. Sage). Thousand Oaks, CA.

Zbaracki, M.J. (1998), "The rhetoric and reality of total quality management," Admin. Sci. Quart., 43, pp. 602-636.

Zimmerman, M.A. and G.J. Zeitz (2002), "Beyond survival: achieving new venture growth by building legitimacy,” Academic Management Review, 27, pp. 414-431.

Zott, C. and R. Amit (2007), "Business model design and the performance of entrepreneurial firms," Organ. Sci., 18, pp. 181-199.

Zott, C. and Q. Huy (2007), "How entrepreneurs use symbolic management to acquire resources," Admin. Sci. Quart., 52, pp. 70-105.

Zucker, L.G. (1986), "The production of trust: institutional sources of economic structure, 18401920," in B.M. Staw and L.L. Cummings (eds.), Res. in Organ. Behav,. 8, pp. 53-111. 


\section{Appendix A}

Affective Sensegiving Actions Conveying Threat

Some founders used brinkmanship tactics, aggression and threat to secure benefits for their ventures in negotiations with investors and suppliers. Christine, the founder of DRINK, illustrated this when she recalled how she had handled her high-profile City lawyers after she found out that they would charge significant fees even though their services had not yielded the desired benefits for the young organization:

[I suggested] to pay small amounts every month, and said that's what it's going to be. You'll either bankrupt me or accept it this way. And because I've come close to bankruptcy, I can say that to them and look them in the eye. Don't mess with me. You push me to do this - it's over. So you choose. (Founder DRINK.)

Such actions may have entailed short-term benefits for the young organization, as Phil (the founder of TECH) suggested when he mentioned how TECH had accelerated its first fundraising round by pressuring prospective financiers to make an equity investment: "We were putting a huge amount of pressure on them, saying we need it early or we're going to feel doubts. They said okay, we're going to do it." The long-term effects of these actions on stakeholders, however, were more difficult to ascertain, and questionable: it is tricky to threaten someone and still build a trustful long-term business relationship.

Research on emotions has found that fear is associated with the perception that the situation is risky, and even increases people's perception of risk in subsequent situations (Johnson and Tversky, 1983; Lerner and Keltner, 2001). Fearful people thus become more risk averse, take less initiative and tend to be less creative. They tend to engage in systematic processing (i.e., careful, detailed analysis of information) to avoid making mistakes as they perceive high uncertainty in the environment (Tiedens and Linton, 2001). All of these behaviors are likely to impair the development of a young firm. 


\section{Appendix B}

Two Contingency Conditions Related to Emotional Assuring, High-touch Interaction as a Moderator

Emotional assuring seems well received when it occurs in a high-touch (that is, proximal, faceto-face) environment. Stakeholders interpreted the founders as approachable, easy to access, and ready to communicate. Sevin, a middle manager at BUDGET, described it this way:

The founders are very contactable, they're very approachable. They're easy to talk to. If I have a problem, I know that I can talk about it. (Middle manager BUDGET.)

Roman, an investor in CONSULT, confirmed this: "I do know that [the founders] operate a very open-door policy. They're both very approachable people." This context is likely to provide opportunities for emotional assuring to be enacted in customized, timely, and situation-specific ways. For example, it encourages employees to express their thoughts and a wide range of emotions. It also fosters respect for personal sensitivities and diverse ways of expressing emotion (Putnam and Mumby, 1993; Martin et al., 1998). Managers can recognize situations in which their employees need emotional support and tailor emotional assuring to their personal needs. Recipients of emotional assuring are more receptive to such influence when the founders take them seriously, understand their problems and believe they can contribute to the company. We speculate that this factor moderates the relation between emotional assuring and resource mobilization: The higher the "touch," the stronger the positive association.

\section{Authenticity As a Moderator}

Our data suggest that authentic founders - that is, those whom stakeholders perceive as true to themselves and honest with others - can be particularly effective at emotional assuring. For example, when one promised investment in DRINK did not materialize, the company could not pay its suppliers (issuing checks that bounced). Rather than hiding these problems, the founders showed authenticity in their symbolic reparative actions to elicit suppliers' comfort.

So we just told the truth. We called the [suppliers and said], "We've had a complete disaster. We've had an investor who was going to come in. We're going to give you £100 out of our own pocket because it's all we've got...We don't have any money in the company at the moment. I don't know what's going to happen. But as a matter of goodwill, we will give it to you from ourselves." And that single gesture saved us. (Founder DRINK.)

The disarming honesty displayed by Christine, the founder, probably increased the calming effect that her symbolic payment had on the suppliers. Why do people value authenticity in business transactions beyond the ethical value of honesty? Research on customer service suggests that a perceived authentic smile directly enhances customer satisfaction because it is evidence of someone's willingness to go beyond task requirements (Grandey and Brauburger, 2002). Conversely, customer satisfaction is diminished by inauthentic actions, such as fake smiles, which are interpreted as crude impression management (Bolino, 1999). These arguments, together with our data, lead us to surmise that the stronger the founder's authenticity, the stronger the positive association between emotional assuring and resource mobilization. 


\section{Appendix C}

From Resource Mobilization to Organization Performance

The importance of the hypothesized link between emotional assuring and resource mobilization can be further assessed by considering key business challenges that the young firms in our sample faced. To do so, we divided our sample into three sub-samples; each included two firms that had to deal with a similar critical business challenge (that the ventures in our sample could be matched according to the similar challenges they faced was fortuitous. This only became clear to us during the data analysis stage, and was not part of our sampling strategy). In each of the three pairs, there was one firm that used emotional assuring heavily. That firm also happened to be the one that dealt successfully with the respective challenge at hand by mobilizing adequate resources. Below, we display the results of this analysis for one pair of firms (DRINK and TECH) who suffered from a lack of product readiness (the remainder of the analysis for the other sample firms can be obtained upon request from the authors).

DRINK and TECH suffered from a lack of marketable products and a scarcity of sales-generated cash. DRINK's main product (whisky) required the construction of a factory. Moreover, it had to store the final product for at least seven years before it attained a quality that could be sold. TECH developed wireless-communication solutions based on radio-frequency technology and required a substantial up-front REtD investment. Although the founders of both firms had been successful in gathering initial resources to launch their ventures (e.g., TECH had raised several million in venture capital financing), both were depleting that initial investment fast, and they faced pressure to obtain additional support.

DRINK was able to mobilize resources from stakeholders to creatively address the adverse conditions that threatened its survival. For example, employees at all levels of the company contributed to the development of a new vodka drink. According to one, "Everyone wanted to be involved, everyone wanted to help. Actually, the name of the vodka was invented by an accountant." In another example, a DRINK board member hand-delivered a product sample to an important customer in Singapore, who had threatened to take business elsewhere after receiving the wrong one. This action resulted in important resource benefits for the venture:

[The board member] walked in one hour before the deadline, undid the suitcases, put the product sample onto the bar and there they were. They were shocked ... They think we walk on water as a result. It turns out that this key buyer also buys for all the Swiss hotels around the world, which is an unexpected benefit, and we got all this press from doing the press release on it. (Founder DRINK.)

TECH faced a similar business challenge in terms of product readiness. For the firm's first two years, it had used its munificent venture capital funding for product development. Then, when Patrick, the founder, believed that the product was ready for market (and venture financiers were becoming increasingly impatient), he switched the company's focus away from product development to marketing and sales. However, sales remained very slow. Some members of the top team believed that the product was still having technical problems, but no one took care of their concerns. One sales director commented: 


\section{Appendix C (continued)}

"If you're out on the front lines you're seeing how everything is working, you're seeing all the holes. I was just coming back and saying, "Boy, guys, this isn't as good as we think it is. There are many problems ...." [The founder] would hear nothing of it. I was basically told that I was going to be fired if I brought it up again." (Sales Director TECH.)

Under pressure, the founder's affective sensegiving actions (indicated in Table 2) discouraged employees from taking initiative. Rather than support the company in new and unexpected ways, like the members of DRINK, "the employees [of TECH] would just end up doing what they were told," noted the new incoming CEO. "[There was] resignation among them." The lack of resource mobilization made the company slide into a downward spiral. Relations among organization members deteriorated, the founder was fired by a divided board of directors and the assets of the company were finally sold.

We can only speculate here that more frequent use of emotional assuring (as practiced, for example, by Christine of DRINK) could have helped TECH deal more constructively with the critical survival challenge of a lack of sales-generated cash. It could have given the young organization some "breathing room" to explore and find alternative approaches to its business problem, and thus tipped the balance toward a more positive outcome. 